\title{
Optimalisasi Aksesibilitas Sebagai Percepatan Pembangunan : Studi Kasus Penataan Jalan di Kabupaten Pangandaran
}

\author{
Bayu Kharisma $^{1}$, Wulan Agustina Triwardani ${ }^{2}$ \\ Departemen Ilmu Ekonomi, Fakultas Ekonomi dan Bisnis, Universitas Padjadjaran \\ Badan Perencanaan Pembangunan Daerah Kota Bekasi
}

\begin{abstract}
Abstrak
Penelitian ini bertujuan untuk menganalisis pelaksanaan pembangunan infrastruktur, khususnya penataan jalan, kebijakan penataan jalan ditinjau dari aspek spasial dan aksesibilitas pembangunan di Kabupaten Pangandaran. Metodologi yang digunakan dalam penelitian ini adalah Konektivitas, Metode USG dan Analisa SWOT. Sumber data yang dijadikan informan adalah Bappeda Kabupaten Pangadaran dan Satuan Kerja Perangkat Daerah (SKPD) dan dokumen RPJMD Kabupaten Pangandaran 2016-2021, Profil Daerah Kabupaten Pangandaran 2106. Peta Tematik Kabupaten Pangandaran yang resmi untuk dijadikan rujukan menganalisa secara spasial. Selain itu, proses pengumpulan data menggunakan metode wawancara disertai permintaan data digital. Hasil penelitian menunjukkan bahwa Pelaksanaan pembangunan infrastruktur terkait penataan jalan di Kabupaten Pangandaran saat ini merupakan prioritas utama kegiatan pembangunan. Hal ini tidak lepas bahwa kondisi jalan yang ada saat ini dapat dikatakan kurang layak dan merupakan warisan dari Kabupaten Ciamis. Kebijakan penataan jalan merupakan hal yang mendesak karena jika ditinjau dari aspek spasial Kabupaten Pangandaran berada pada wilayah yang rawan bencana. Disisi lain, kondisi topologi dan geografi Kabupaten Pangandaran yang penuh tantangan menjadi alasan tersendiri menjadi prioritas. Aksesibilitas dapat meningkatan percepatan pembangunan di Kabupaten Pangandaran karena letak Kabupaten Pangandaran yang strategis dan menjadi jalur daerah tujuan wisata.
\end{abstract}

Kata kunci : pembangunan infrastruktur, aspek spasial, aksesibilitas pembangunan, konektivitas, metode USG, analisa SWOT

\begin{abstract}
This study aims to analyze the implementation of infrastructure development, especially the arrangement of roads, road management policy in terms of spatial aspects and accessibility of development in Pangandaran Regency. The methodology used in this research is Connectivity, Ultrasound Method and SWOT Analysis. Source of data used as informants is Bappeda Pangadaran District and Local Government Work Unit (SKPD) and RPJMD document Pangandaran District 2016-2021, Regional Profile of Regency Pangandaran 2106. The official map of Pangandaran Regency to be used as reference to analyze spatially. In addition, the process of collecting data using interview methods accompanied the demand for digital data. The results showed that the implementation of infrastructure development related to road arrangement in Pangandaran Regency is currently the main priority of development activities. It is not separated that the existing road conditions can be said to be less feasible and is a legacy of Ciamis regency. The policy of road arrangement is urgent because if viewed from the spatial aspect of Pangandaran Regency is in disaster-prone areas. On the other hand, the challenging condition of topology and geography of Pangandaran Regency becomes its own reasons. Accessibility can increase the acceleration of development in Pangandaran regency due to the strategic location of Pangandaran Regency and become a tourist destination.
\end{abstract}

Keywords: infrastructure development, spatial aspects, development accessibility, connectivity, USG methods, SWOT analysis

${ }^{1}$ Corresponding author, email address: ${ }^{1}$ bayu.kharisma@unpad.ac.id 


\section{LATAR BELAKANG}

Berdasarkan undang-undang No. 23 Tahun 2014 tentang otonomi daerah memberikan kesempatan bagi berkembangnya daerah-daerah baru yang ada di wilayah Indonesia. Otonomi daerah di Indonesia adalah hak, wewenang, dan kewajiban daerah otonom untuk mengatur dan mengurus sendiri urusan pemerintahan dan kepentingan masyarakat setempat sesuai dengan peraturan perundang-undangan. Pangandaran merupakan salah satu daerah otonomi baru yang memekarkan diri dari Kabupaten Ciamis, sejak disahkannya Undang-undang No. 21 Tahun 2012 Tentang Pembentukan Kabupaten Pangandaran Di Provinsi Jawa Barat. Sebagaimana diketahui bahwa terdapat banyak kendala yang dimiliki oleh Kabupaten Ciamis sehingga mengakibatkan adanya dorongan bagi Pangandaran yang secara potensi memiliki banyak keunggulan untuk memisahkan diri menjadi daerah otonom sendiri. Salah satu poin penting yang menjadi masalah utama terjadinya pemekaran wilayah Pangandaran ini terkait kesejahteraan penduduk di Kabupaten Ciamis, permasalahan kesejahteraan ini relatif terfokus pada daerah bagian utara Kabupaten Ciamis. Sementara bila ditinjau dari Produk Domestik Regional Bruto (PDRB) perkapita dari sisi nonmigas, wilayah Ciamis bagian selatan yang notabene adalah Pangadaran memiliki andil besar daripada wilayah utara dan tengah.

Berdasarkan luas wilayah dan besarnya jumlah penduduk yang dimiliki Kabupaten Ciamis serta terjadinya ketimpangan yang sangat jelas pada wilayah bagian selatan, sudah selayaknya Pangandaran menjadi daerah otonomi baru. Maka sejak tanggal 17 November 2012 secara legal formal diresmikanlah daerah otonom baru bernama Kabupaten Pangandaran. Diharapkan dengan pembentukan Kabupaten Pangandaran ini pelaksanaan pembangunan dan pelayanan kepada masyarakat dapat terjangkau sehingga pelayananan publik dapat ditingkatkan guna mempercepat terwujudnya kesejahteraan masyarakat daerah pesisir selatan Jawa Barat.

Menjadi Kabupaten yang baru saja memekarkan diri merupakan hal yang tidak mudah, tetapi bukan berarti dijadikan alasan ketidakmampaun bagi daerah otonom baru untuk mengembangkan potensi yang dimilikinya. Dalam hal ini Kabupaten Pangadaran memiliki salah satu potensi di bidang pariwisata yang menjadi andalan bagi peningkatan pendapatan yang secara tidak langsung berdampak pada kesejahteraan masyarakat nantinya. Sebagai daerah otonom baru, Kabupaten Pangandaran perlu melakukan berbagai upaya peningkatan kemampuan ekonomi, dan peningkatan sumber daya manusia dengan pembangunan sarana dan prasarana untuk menunjang segala aktivitas masyarakat. 
Kabupaten Pangadaran memiliki pertimbangan yang sangat matang sehingga memutuskan untuk memisahkan diri dari Kabupaten Ciamis. Pertimbangan tersebut adalah potensi wisata dan alam yang dimiliki Kabupaten Pangadaran merupakan tonggak utama penggerak perekonomian masyarakat di Pangandaran selain sektor perikanan dan kelautan yang notabene adalah mata pencahariaan sebagian masyarakatnya. Ketersediaan infrastruktur berupa jalan masih menjadi masalah signifikan yang dialami masyarakat Kabupaten Pangandaran, sehingga konektivitas antar kecamatan cukup terkendala. Disamping itu akses ke lokasi wisata yang menjadi icon Kabupaten Pangandaran masih terasa minim, ini menyebabkan potensi utama daerah otonom baru ini masih belum tergali maksmimal.

Kondisi tersebut dinilai dapat dimaklumi dan wajar terjadi pada daerah otonom baru seperti Kabupaten Pangandaran dengan luas wilayah sebesar 101.092 Ha, yang tidak dengan mudah dapat menyelesaikan permasalahan konektivitas ini selesai pada tahun pertama pembentukannya. Oleh karena ini perlu dilakukan akselerasi yang dikhususkan kepada pembangunan jalan agar konektivitas antar daerah otonom baru ini dapat terwujud. Berdasarkan dokumen Rencana Pembangunan Jangka Menengah Daerah Kabupaten Pangandaran Tahun 2016-2021 permasalahan yang dihadapi kabupaten Pangandaran berhubungan dengan masalah Spasial adalah sebagai berikut: (1) belum optimalnya koordinasi kelembagaan di daerah otonomi baru Kabupaten Pangandaran; (2) kurangnya penataan Pedagang Kaki Lima (PKL) di lokasi-lokasi pariwisata; (3) dan masih terkendalanya pengendalian pemanfaatan ruang melalui analisis daya dukung dan daya tampung lingkungan. Berdasarkan latar belakang tersebut maka dalam penelitian ini dirumuskan permasalahan sebagai berikut: (1) bagaimana pelaksanaan pembangunan infrastruktur khususnya penataan jalan di Kabupaten Pangandaran; (2) bagaimana kebijakan penataan jalan ditinjau dari aspek spasial di Kabupaten Pangandaran? (3) bagaimana aksesibilitas dapat mempercepat pembangunan di Kabupaten Pangandaran?

\section{LANDASAN TEORI}

Sesuai dengan permasalahan yang dirumuskan dalam penelitian ini, sebagai landasan teori akan dibahas tentang Konektivitas (Evans, 2009), Metode USG (Kepner, C.H. \& Benjamin, T.B., 1981) dan Analisa SWOT. Penjelasan mengenai tiga landasan teori tersebut akan disampaikan sebagai berikut:

\section{A. Konektivitas}


Interaksi keruangan merupakan suatu hubungan timbal balik (resiprocal relationship) yang saling berpengaruh antara dua wilayah atau lebih yang dapat menimbulkan gejala, kenampakan, atau permasalahan baru. Kuat-lemahnya interaksi sangat dipengaruhi oleh tiga faktor utama, yaitu adanya wilayah-wilayah yang saling melengkapi (regional complementary), adanya kesempatan untuk berintervensi (intervening opportunity), serta adanya kemudahan transfer atau pemindahan dalam ruang (spatial transfer ability). Para ahli banyak yang mengembangkan teori interaksi spasial, seperti K.J. Kansky dan W.J. Reilly. Aplikasi teori-teori interaksi dapat diterapkan dalam perencanaan pembangunan. Misalnya, penempatan lokasi pusat pelayanan masyarakat, pembangunan prasarana transportasi yang dapat membuka keterasingan suatu wilayah dari wilayah lain, dan kemajuan informasi serta teknologi. Teori interaksi keruangan memiliki tiga teori turunan antara lain Model Gravitasi, Teori Titik Henti, dan Teori Grafik yang akan dijelaskan sebagai berikut:

1) Model Gravitasi

Teori Gravitasi kali pertama diperkenalkan dalam disiplin ilmu Fisika oleh Sir Issac Newton pada tahun 1687 (Oppenheim, 1980). Model gravitasi Newton ini kemudian diterapkan oleh W.J. Reilly (1929), seorang ahli geografi untuk mengukur kekuatan interaksi keruangan antara dua wilayah atau lebih. Berdasarkan hasil penelitiannya, Reilly berpendapat bahwa kekuatan interaksi antara dua wilayah yang berbeda dapat diukur dengan memperhatikan faktor jumlah penduduk dan jarak antara kedua wilayah tersebut. Perbandingan potensi interaksi antarwilayah dengan memanfaatkan formula yang dikemukakan Reilly ini dapat diterapkan jika kondisi wilayah-wilayah yang dibandingkan memenuhi persyaratan tertentu. Adapun persyaratan tersebut antara lain sebagai berikut:

a. Kondisi sosial-ekonomi, tingkat pendidikan, mata pencarian, mobilitas, dan kondisi sosial-budaya penduduk setiap wilayah yang dibandingkan relatif memiliki kesamaan;

b. Kondisi alam setiap wilayah relatif sama, terutama berkaitan dengan kondisi topografinya;

c. Keadaan sarana dan prasarana transportasi yang menghubungkan wilayahwilayah yang dibandingkan relatif sama;

Ketiga persyaratan tersebut berdasarkan kenyataan bahwa secara teoretis potensi wilayah A untuk berinteraksi dengan wilayah B cenderung jauh lebih besar 
dibandingkan antara wilayah B dan C. Namun, jika kondisi prasarana transportasi yang menghubung kan wilayah $\mathrm{B}$ dan $\mathrm{C}$ jauh lebih baik jika dibandingkan antara $\mathrm{A}$ dan B, tetap saja potensi interaksi antara B dan C akan jauh lebih besar. Demikian pula halnya dengan persyaratan lainnya, yaitu kondisi kependudukan dan topografi dari suatu wilayah.

2) Teori Titik Henti (Breaking Point Theory)

Teori Titik Henti (Breaking Point Theory) merupakan hasil modifikasi dari Model Gravitasi Reilly (Robinson, 2004). Teori ini memberikan gambaran tentang perkiraan posisi garis batas yang memisahkan wilayah-wilayah perdagangan dari dua kota atau wilayah yang berbeda jumlah dan komposisi penduduknya. Teori Titik Henti juga dapat digunakan dalam memperkirakan penempatan lokasi industry atau pusat pelayanan masyarakat. Penempatan dilakukan di antara dua wilayah yang berbeda jumlah penduduknya agar terjangkau oleh penduduk setiap wilayah. Menurut teori ini jarak titik henti (titik pisah) dari lokasi pusat perdagangan (atau pelayanan sosial lainnya) yang lebih kecil ukurannya adalah berbanding lurus dengan jarak antara kedua pusat perdagangan. Namun, berbanding terbalik dengan satu ditambah akar kuadrat jumlah penduduk dari kota atau wilayah yang penduduknya lebih besar dibagi jumlah penduduk kota yang lebih sedikit penduduknya.

3) Teori Grafik

Untuk menganalisis potensi kekuatan interaksi antarwilayah ditinjau dari struktur jaringan jalan sebagai prasarana transportasi, K.J. Kansky mengembangkan Teori Grafik dengan membandingkan jumlah kota atau daerah yang memiliki banyak rute jalan sebagai sarana penghubung kota-kota tersebut (Lutfi., 1999). Menurut Kansky, kekuatan interaksi ditentukan dengan Indeks Konektivitas. Semakin tinggi nilai indeks, semakin banyak jaringan jalan yang menghubungkan kota-kota atau wilayah yang sedang dikaji. Hal ini tentunya berpengaruh terhadap potensi pergerakan manusia, barang, dan jasa karena prasarana jalan sangat memperlancar tingkat mobilitas antarwilayah. Dalam kaitannya dengan perencanaan pembangunan wilayah, analisis indeks konektivitas dapat dijadikan salah satu indikator dan pertimbangan untuk merencanakan pembangunan infrastruktur jalan serta fasilitas transportasi lainnya. Dengan analisis indeks konektivitas dapat meningkat kan hubungan suatu wilayah dengan wilayah-wilayah lainnya, serta memperlancar arus pergerakan 
manusia, barang, dan jasa yang pada akhirnya dapat meningkatkan kesejahteraan masyarakat.

\section{B. Metode USG}

Urgency, Seriousness, Growth (USG) adalah salah satu alat untuk menyusun urutan prioritas isu yang harus diselesaikan. Caranya dengan menentukan tingkat urgensi, keseriusan, dan perkembangan isu dengan menentukan skala nilai $1-5$ atau $1-10$. Isu yang memiliki total skor tertinggi merupakan isu prioritas. Penjelasan mengenai urgency, seriousness, dan growth dijabarkan sebagai berikut:

\section{1) Urgency}

Seberapa mendesak isu tersebut harus dibahas dikaitkan dengan waktu yang tersedia serta seberapa keras tekanan waktu tersebut untuk memecahkan masalah yang menyebabkan isu tersebut.

\section{2) Seriousness}

Seberapa serius isu tersebut perlu dibahas dikaitkan dengan akibat yang timbul dengan penundaan pemecahan masalah yang menimbulkan isu tersebut atau akibat yang menimbulkan masalah-masalah lain kalau masalah penyebab isu tidak dipecahkan. Perlu dimengerti bahwa dalam keadaan yang sama, suatu masalah yang dapat menimbulkan masalah lain adalah lebih serius bila dibandingkan dengan suatu masalah lain yang berdiri sendiri.

3) Growth

Seberapa kemungkinan-kemungkinannya isu tersebut menjadi berkembang dikaitkan kemungkinan masalah penyebab isu akan makin memburuk kalau dibiarkan.

Metode USG merupakan salah satu cara menetapkan urutan prioritas masalah dengan metode teknik scoring. Proses untuk metode USG dilaksanakan dengan memperhatikan urgensi dari masalah, keseriusan masalah yang dihadapi, serta kemungkinan berkembangnya masalah tersebut semakin besar. Hal tersebut dapat dijelaskan sebagai berikut:

1) Urgency atau urgensi, yaitu dilihat dari tersedianya waktu, mendesak atau tidak masalah tersebut diselesaikan.

2) Seriousness atau tingkat keseriusan dari masalah, yakni dengan melihat dampak masalah tersebut terhadap produktifitas kerja, pengaruh terhadap keberhasilan, membahayakan system atau tidak. 
3) Growth atau tingkat perkembangan masalah yakni apakah masalah tersebut berkembang sedemikian rupa sehingga sulit untuk dicegah.

Penggunaan metode USG dalam penentuan prioritas masalah dilaksanakan apabila pihak perencana telah siap mengatasi masalah yang ada, serta hal yang sangat dipentingkan adalah aspek yang ada dimasyarakat dan aspek dari masalah itu sendiri.

\section{Analisa SWOT}

Analisis SWOT adalah instrumen yang digunakan untuk melakukan analisis strategis (Rangkuti, 2001). Analisis SWOT merupakan suatu alat yang efektif dalam membantu menstrukturkan masalah, terutama dengan melakukan analisis atas lingkungan strategis, yang lazim disebut sebagai lingkungan internal dan lingkungan eksternal. Dalam lingkungan internal dan eksternal ini pada dasarnya terdapat empat unsur yang selalu dimiliki dan dihadapi, yaitu secara internal memiliki sejumlah kekuatan (strenghts) dan kelemahan (weaknesses) dan secara eksternal akan berhadapan dengan berbagai peluang (opportunity) dan ancaman (Threats) Kegiatan yang paling penting dalam proses analisis SWOT adalah memahami seluruh informasi dalam suatu kasus, menganalisis situasi untuk mengetahui isu apa yang sedang terjadi dan memutuskan tindakan apa yang harus segera dilakukan untuk memecahkan masalah (Freddy Rangkuti, 2001:14). SWOT merupakan singkatan dari kekuatan (strenghts), kelemahan (weaknesses), peluang (opportunity) dan ancaman (Threats) dalam analisis SWOT adalah sebagai berikut :

1) Kekuatan (strenghts)

Kekuatan adalah sumber daya, keterampilan atau keunggulan lain relatif terhadap pesaing dan kebutuhan.

2) Kelemahan (weaknesses)

Kelemahan adalah keterbatasan dalam sumber daya alam, keterampilan, dan kemampuan yang secara serius menghalangi kinerja efektif.

3) Peluang (opportunities)

Peluang adalah situasi/kecenderungan utama yang menguntungkan dalam lingkungan.

4) Ancaman (Threats)

Ancaman adalah situasi/kecenderungan utama yang tidak menguntungkan dalam lingkungan. 
Analisis ini didasarkan pada logika yang dapat memaksimalkan kekuatan dan peluang, namun secara bersamaan dapat meminimalkan kelemahan dan ancaman. Proses pengambilan keputusan harus menganalisis faktor-faktor strategis dalam kondisi saat ini. Hal ini disebut dengan analisis situasi, model yang paling populer disebut analisis SWOT. Petunjuk umum yang sering diberikan untuk perumusan adalah :

- Memanfaatkan kesempatan dan kekuatan (O dan S)

Analisis ini diharapkan membuahkan rencana jangka panjang.

- Atasi atau kurangi ancaman dan kelemahan (T dan W)

Analisa ini lebih condong menghasikan rencana jangka pendek, yaitu rencana perbaikan (short-term improvement plan).

Dapat disimpulkan bahwa analisis SWOT adalah perkembangan hubungan atau interaksi antar unsur-unsur internal, yaitu: kekuatan dan kelemahan terhadap unsur-unsur eksternal yaitu peluang dan ancaman. Di dalam penelitian analisis SWOT kita ingin memperoleh hasil berupa kesimpulan berdasarkan ke-4 faktor Dwimuka yang sebelumnya telah dianalisa.

1) Strategi Kekuatan-Peluang ( $\mathrm{S}$ dan $\mathrm{O}$ atau Maxi-Maxi)

Strategi yang dihasilkan pada kombinasi ini adalah memanfaatkan kekuatan atas peluang yang telah diidentifikasi

2) Strategi Kelemahan-Peluang ( $\mathrm{W}$ dan $\mathrm{O}$ atau Mini-Maxi)

Kesempatan yang dapat diidentifikasi tidak mungkin dimanfaatkan karena kelemahan perusahaan

3) Strategi Kekuatan-Ancaman (S dan T atau Maxi-Mini)

Dalam analisa ancaman ditemukan kebutuhan untuk mengatasinya. Strategi ini mencoba mencari kekuatan yang dimiliki perusahaan yang dapat mengurangi atau menangkal ancaman tersebut.

4) Strategi Kelemahan-Ancaman (W dan $Y$ atau Mini-Mini)

Dalam situasi menghadapi ancaman dan sekaligus kelemahan intern, strategi yang umumnya dilakukan adalah "keluar" dari situasi yang terjepit tersebut. Keputusan yang diambil adalah "mencairkan" sumber daya yang terikat pada situasi yang mengancam tersebut, dan mengalihkannya pada usaha lain yang lebih cerah. Siasat lainnya adalah mengadakan kerja sama dengan satu perusahaan yang lebih kuat, dengan harapan ancaman di suatu saat akan hilang 


\section{KONDISI GEOGRAFI}

Kabupaten Pangandaran merupakan kabupaten hasil pemekeran wilayah Kabupaten Ciamis di Provinsi Jawa Barat yang ditetapkan pada tahun 2012 berdasarkan Undang-Undang Nomor 21 Tahun 2012. Secara geografis wilayah Kabupaten Pangandaran berada pada $108^{0} 30^{\prime}$ - 108 $40^{\prime}$ BT dan $7^{0} 40^{\prime} 20^{\prime \prime}$ - 7 $7^{0} 50^{\prime} 20^{\prime}$ ' LS. Dilihat dari peta Jawa Barat, Kabupaten Pangandaran terletak paling tenggara berbatasan dengan Kabupaten Ciamis dan Kota Banjar di sebelah utara, sebelah barat dengan Kabupaten Ciamis dan Kabupaten Tasikmalaya, berbatasan Provinsi Jawa Tengah di sebelah timur, dan dibagian selatan berbatasan dengan Samudera Indonesia.

Luas Kabupaten Pangandaran $\pm 1.011,69 \mathrm{Km}^{2}$ dan memilih Kecamatan Parigi sebagai Ibukota Kabupaten yang berada di sebelah barat dari peta Kabupaten Pangandaran. Cakupan wilayah Kabupaten Pangandaran terdiri dari 10 kecamatan, yaitu: Kec. Parigi, Kec. Cijulang, Kec. Cimerak, Kec. Cigugur, Kec. Langkaplancar, Kec. Mangunjaya, Kec. Padaherang, Kec. Kalipucang, Kec. Pangandaran, Kec. Sidamulih. Distribusi luasan untuk masing-masing kecamatan tersebut dapat dilihat pada Tabel 1. di bawah ini.

Tabel 1

Luas Administratif Kecamatan di Kabupaten Pangandaran

\begin{tabular}{|c|c|c|}
\hline No. & Kecamatan & Luas Wilayah $\left(\mathbf{K m}^{2}\right)$ \\
\hline 1. & Cimerak & 118,18 \\
\hline 2. & Cijulang & 93,16 \\
\hline 3. & Cigugur & 97,29 \\
\hline 4. & Langkaplancar & 177,19 \\
\hline 5. & Parigi & 98,04 \\
\hline 6. & Sidamulih & 77,98 \\
\hline 7. & Pangandaran & 60,77 \\
\hline 8. & Kalipucang & 136,78 \\
\hline 9. & Padaherang & 89,27 \\
\hline 10. & Mangunjaya & 63,03 \\
\hline & Jumlah & $1.011,69$ \\
\hline
\end{tabular}

Sumber: RPJMD Kabupaten Pangandaran 2016 - 2021

Berdasarkan Undang-Undang Nomor 21 Tahun 2012, batas administratif wilayah Kabupaten Pangandaran adalah sebagai berikut:

a. Sebelah utara berbatasan dengan Desa Ciulu, Desa Pasawahan, Desa Cikupa Kecamatan Banjarsari, Desa Sidarahayu Kecamatan Purwadadi, Desa Sidamulih Kecamatan Pamarican Kabupaten Ciamis dan Desa Citalahab Kecamatan Karangjaya, Desa Cisarua Kecamatan Cineam Kabupaten Tasikmalaya; 
b. Sebelah timur berbatasan dengan Desa Tambaksari, Desa Sidanegara, Desa Rejamulya Kecamatan Kedungreja, Desa Sidamukti, Desa Patimuan, Desa Rawaapu, Desa Cinyawang, Desa Purwodadi Kecamatan Patimuan Kabupaten Cilacap Provinsi Jawa Tengah;

c. Sebelah selatan berbatasan dengan Samudera Hindia; dan

d. Sebelah barat berbatasan dengan Desa Pasangrahan Kecamatan Cikatomas, Desa Neglasari, Desa Tawang, Desa Panca Wangi, Desa Mekarsari Kecamatan Pancatengah, Desa Cimanuk Kecamatan Cikalong, Desa Mulyasari Kecamatan Salopa Kabupaten Tasikmalaya Secara lebih detil batas administratif Kabupaten Pangandaran dapat dilihat pada Gambar 1 berikut ini.

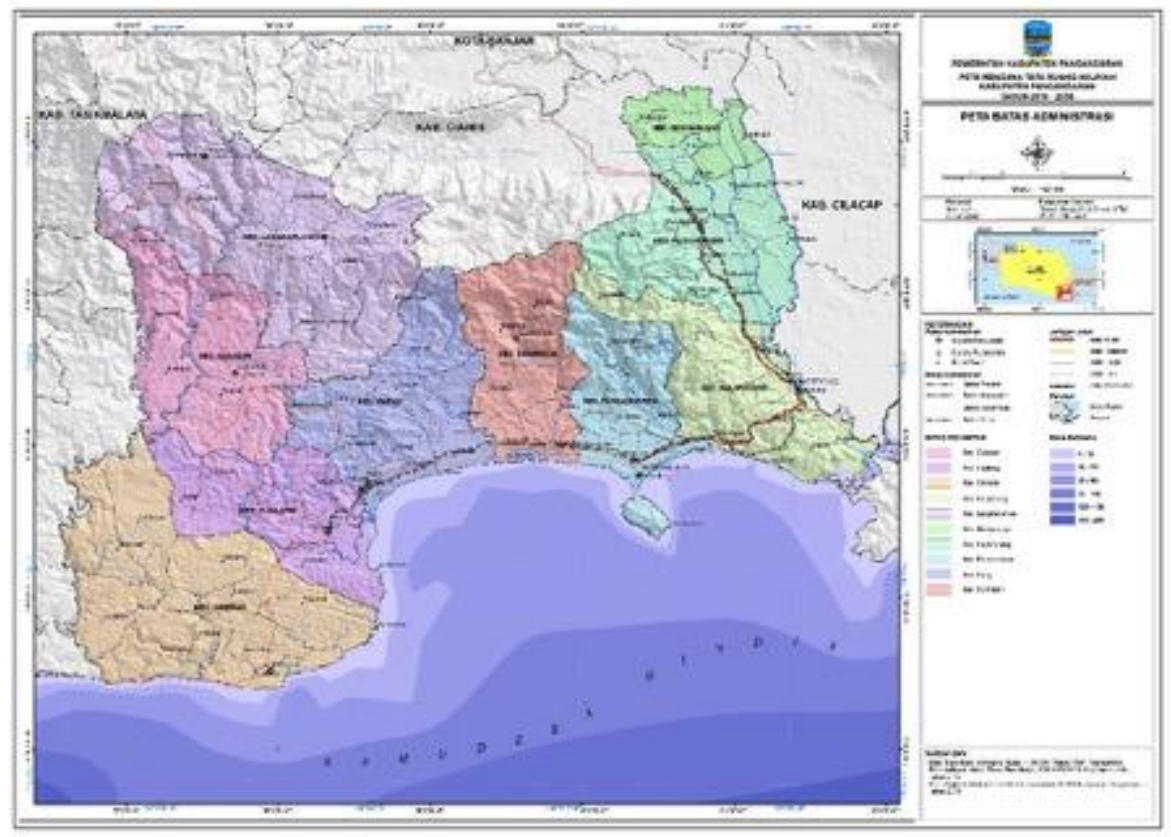

Gambar 1 Peta Batas Administratif Kabupaten Pangandaran Sumber: RPJMD Kabupaten Pangandaran 2016 - 2021

Dilihat dari kondisi topografi Kabupaten Pangandaran berada pada ketinggian antara 0 - 700 mdpl denga sudut elevasi cenderung meninggi dari selatan ke utara, kecuali bagian barat pesisir yang merupakan perbukitan karet. Terkait kondisi topografi di Kabupaten Pangandaran dapat dilihat Tabel 2 di bawah ini.

Tabel 2

Kondisi Topografi Kabupaten Pangandaran per Kecamatan

\begin{tabular}{|c|l|c|}
\hline No & Kecamatan & Kondisi Topografi Kabupaten Pangandaran \\
\hline 1 & Cimerak & $\bullet$ Kondisi geografis: bagian selatan dominan pesisir bertebing \\
\hline
\end{tabular}




\begin{tabular}{|c|c|c|}
\hline No & Kecamatan & Kondisi Topografi Kabupaten Pangandaran \\
\hline & & $\begin{array}{l}\text { curam dan ke bagian utara merupakan perbukitan kapur. } \\
\text { - Ketinggian: 3-80 mdpl dengan daerah dataran rendah atau } \\
\text { pantai. }\end{array}$ \\
\hline 2 & Cijulang & $\begin{array}{l}\text { - Merupakan kecamatan yang berada di daerah pesisir pantai. } \\
\text { - Ketinggian: 2-185 mdpl dengan daerah dataran rendah/pantai. }\end{array}$ \\
\hline 3 & Cigugur & $\begin{array}{l}\text { - Wilayah ini merupakan daerah bukan pesisir melainkan } \\
\text { perbukitan dan dataran tinggi. } \\
\text { - Ketinggian wilayah di Kecamatan Cigugur relatif sama antara } \\
\text { 200-500 mdpl. }\end{array}$ \\
\hline 4 & Langkaplancar & $\begin{array}{l}\text { - Wilayah ini bukan pesisir melainkan dataran tinggi. } \\
\text { - Ketinggian wilayah di Kecamatan Langkaplancar relatif sama } \\
\text { antara 400-1.000 mdpl. }\end{array}$ \\
\hline 5 & Parigi & $\begin{array}{l}\text { - Ketinggian wilayah bervariasi antara 5-500 mdpl } \\
\text { - Desa yang berada di dataran rendah yakni Desa Parigi, } \\
\text { Karangjaladri, Cibenda, Karangbenda dan Ciliang. }\end{array}$ \\
\hline 6 & Sidamulih & $\begin{array}{l}\text { - Merupakan kecamatan yang berada di daerah pesisir pantai. } \\
\text { - Ketinggian: 3-250 mdpl dengan daerah dataran tingginya yakni } \\
\text { desa Kersaratu dan Kalijati. }\end{array}$ \\
\hline 7 & Pangandaran & $\begin{array}{l}\text { - Merupakan daerah pesisir pantai, merupakan ODTW Nasional } \\
\text { dan memiliki Cagar Alam yang dilindungi. } \\
\text { - Ketinggian: 3-500 mdpl. }\end{array}$ \\
\hline 8 & Kalipucang & $\begin{array}{l}\text { - Ketinggian wilayah bervariasi antara 2-400 mdpl, dengan desa } \\
\text { yang berada di dataran tinggi yakni Desa Ciparakan (400 mdpl) } \\
\text { dan Emplak (160 mdpl). } \\
\text { - Daerah lainnya merupakan dataran rendah berkisar antara 2-8 } \\
\text { mdpl. }\end{array}$ \\
\hline 9 & Padaherang & $\begin{array}{l}\text { - Wilayah ini bukan pesisir. } \\
\text { - Ketinggian wilayah di Kecamatan Padaherang bervariasi antara } \\
13-600 \text { mdpl. } \\
\text { - Daerah yang berada di dataran tinggi yakni Desa Panyutran } \\
\text { (600 mdpl) dan Bojongsari ( } 245 \text { mdpl). } \\
\text { - Sedangkan daerah lainnya merupakan dataran yang realtif } \\
\text { sama berkisar antara } 13-24 \text { mdpl. }\end{array}$ \\
\hline 10 & Mangunjaya & $\begin{array}{l}\text { - Wilayah ini merupakan daerah bukan pesisir. } \\
\text { - Ketinggian wilayah di Kecamatan Mangunjaya relatif sama } \\
\text { antara 13-17 mdpl. }\end{array}$ \\
\hline
\end{tabular}

Sumber: RPJMD Kabupaten Pangandaran 2016 - 2021

Jika dilihat dari kondisi kemiringan lerengnya, Kabupaten Pangandaran memiliki kemiringan lereng yang bervariasi antara $0 \%$ hingga lebih dari $40 \%$. Kemiringan lereng yang besar terdapat di daerah perbukitan dan terdapat gawir sesar di bagian tengah timur Kabupaten Pangandaran yang memanjang arah tenggara-barat laut sehingga kemiringan lerengnya sangat curam. Wilayah dengan kemiringan lereng > 40\% perlu dijaga karena berpotensi menimbulkan kebencanaan apabila tidak dikelola dengan baik. Gambaran sebaran 
topografi dan kemiringan lereng pada Kabupaten Pangandaran dapat dilihat pada Gambar 2 dan 3 di bawah ini.

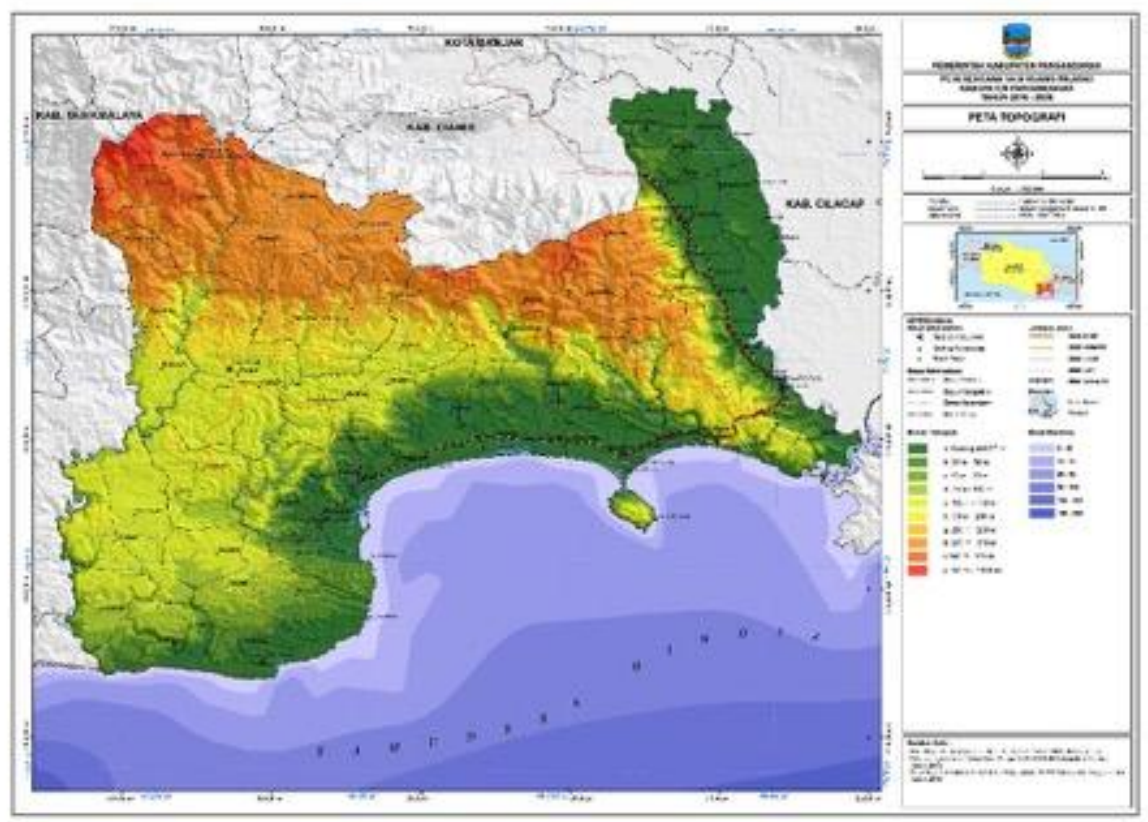

Gambar 2. Peta Topografi Kabupaten Pangandaran Sumber: RPJMD Kabupaten Pangandaran 2016 - 2021

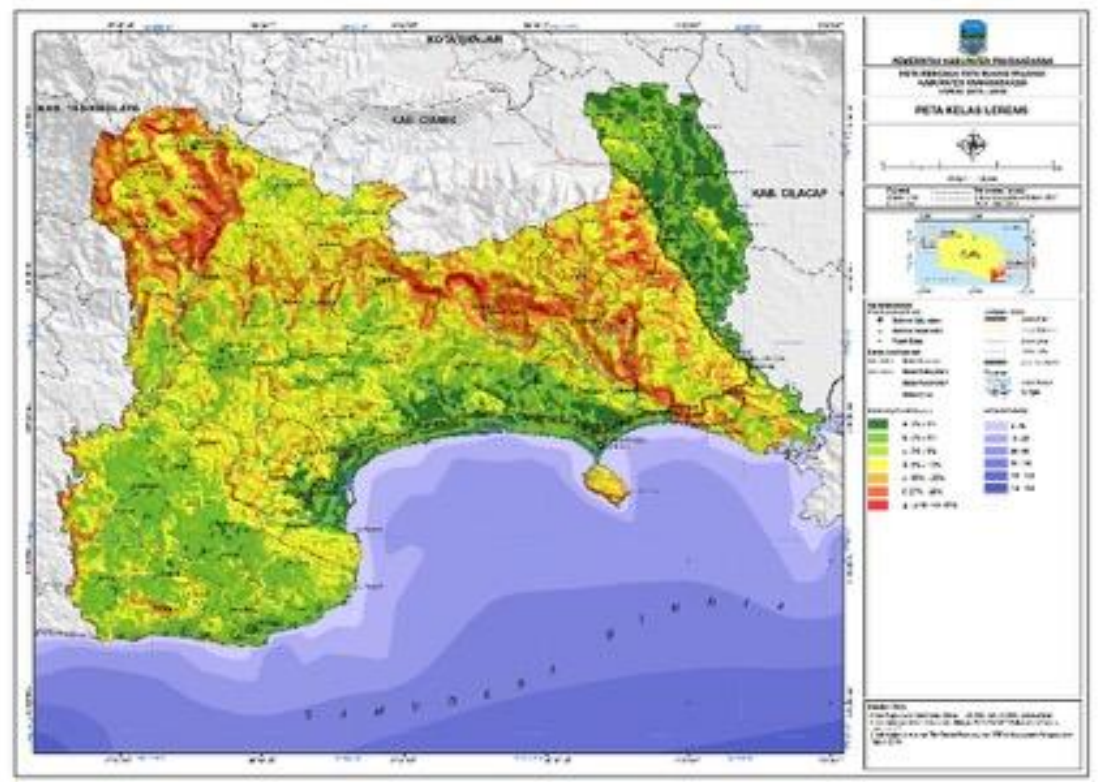

Gambar 3 Peta Kelas Lereng Kabupaten Pangandaran Sumber: RPJMD Kabupaten Pangandaran 2016 - 2021

Ditinjau dari kondisi demografi, berdasarkan data tahun 2014 Kabupaten Pangandaran memiliki jumlah penduduk sebanyak 456.500 orang. Persebaran penduduk terbanyak berada di Kec. Pangandaran sebesar $17 \%$ dengan kepadatan penduduk sebanyak 
1.276 orang $/ \mathrm{km}^{2}$. Secara lebih rinci mengenai kondisi demografi di Kabupaten Pangandaran, dapat dilihat pada Tabel 3.

Tabel 2

Kondisi Demografi di Kabupaten Pangandaran Akhir Tahun 2014

\begin{tabular}{|r|l|c|c|c|c|}
\hline No. & \multicolumn{1}{|c|}{ Kecamatan } & $\begin{array}{c}\text { Luas } \\
\text { Wilayah } \\
\left(\mathbf{K m}^{\mathbf{2}}\right)\end{array}$ & $\begin{array}{c}\text { Jumlah } \\
\text { Penduduk }\end{array}$ & $\begin{array}{c}\text { Kepadatan } \\
\text { Penduduk } \\
\left(\mathbf{O r a n g} / \mathbf{K m}^{\mathbf{2}}\right)\end{array}$ & $\begin{array}{c}\text { Distribusi } \\
\text { Penduduk } \\
(\mathbf{\%})\end{array}$ \\
\hline 1 & Cimerak & 98 & 48,201 & 492 & 11 \\
\hline 2 & Cijulang & 93 & 29,390 & 316 & 6 \\
\hline 3 & Cigugur & 118 & 51,703 & 438 & 11 \\
\hline 4 & Langkaplancar & 97 & 23,940 & 247 & 5 \\
\hline 5 & Parigi & 177 & 53,837 & 304 & 12 \\
\hline 6 & Sidamulih & 78 & 36,035 & 462 & 8 \\
\hline 7 & Pangandaran & 61 & 77,857 & 1,276 & 17 \\
\hline 8 & Kalipucang & 137 & 43,512 & 318 & 10 \\
\hline 9 & Padaherang & 119 & 60,817 & 511 & 13 \\
\hline 10 & Mangunjaya & 33 & 31,208 & 946 & 7 \\
\hline \multicolumn{2}{|c|}{ Kabupaten } & 1,011 & 456,500 & 5,310 & 100 \\
\hline
\end{tabular}

Sumber: RPJMD Kabupaten Pangandaran 2016 - 2021

Berdasarkan tabel diatas tersebut dapat dikatakan bahwa secara umum Kabupaten Pangandaran memiliki potensi berupa SDM yang siap mengembangkan potensi pariwisata. Hal tersebut ditunjukan dengan persebaran penduduk terfokus di Kec. Pangandaran yang notabene wilayah pesisir dengan daya tarik pemandangan pantai.

\section{METODE PENELITIAN}

\subsection{Ruang Lingkup Penelitian}

Mengingat luasnya kemungkinan pembahasan masalah yang akan dilakukan, maka kami sebagai penulis membatasi ruang lingkup masalah agar pembahasan dapat lebih terfokus dan tujuan penulisan dapat tercapai. Adapun ruang lingkup permasalahan dalam penelitian ini hanya membahas pada aspek spasial, yang terfokus pada masalah aksesibilitas di Kabupaten Pangandaran.

\subsection{Dasar Penelitian}

Penelitian yang kami buat ini menggunaka metode observasi lapangan dengan pendekatan kualitatif. Adapun pendekatan kualitatif ini menggunakan data-data deskriptif yang diambil dari informan atau narasumber yang berkompeten dibidangnya. Proses pengumpulan data dilakukan dengan wawancara singkat dan berbagai data sekunder yang 
diberikan terkait tema untuk penelitian ini. Secara teori dapat dikatakan bahwa penelitian dengan menggunakan pendekatan kualitatif ini dapat mengkaji atau membuktikan kebenaran dari suatu teori yang sudah ada dan dikembangkan lagi dengan data-data yang dikumpulkan saat observasi lapangan tersebut.

\subsection{Sumber Data}

Sumber data merupakan subjek dari mana data dapat diperoleh. Adapun yang menjadi sumber data dalam penelitian ini adalah sebagai berikut:

A. Informan

Informan merupakan sumber data yang berupa orang, dalam penelitian ini yang dijadikan informan adalah Pejabat dilingkungan Bappeda Kabupaten Pangadaran serta Satuan Kerja Perangkat Daerah (SKPD) terkait yang menjadi fokus penelitian. Adapun SKPD yang dimaksud adalah Dinas Pekerjaan Umum Tata Ruang Perumahan Rakyat dan Kawasan Permukiman (PUTRPRKP). Dari beberapa infoman tersebut diharapkan dapat menggali berbagai informasi berupa data yang dibutuhkan sebagai bahan untuk mempetajan penelitian ini.

B. Dokumen

Dokumen merupakan bahan tertulis baik fisik maupun digital yang dijadikan rujukan untuk memperkuat hasil analisa dalam penelitian ini. Dalam penelitian ini dokumen yang digunakan adalah dokumen resmi yang memiliki kekuatan hukum sehingga penggunaannya dapat dipetanggungjawabkan. Adapun dokumen yang kami gunakan adalah Dokumen RPJMD Kabupaten Pangandaran 2016 - 2021, Profil Daerah Kabupaten Pangandaran 2106, serta Peta-Peta Tematik Kabupaten Pangandaran yang resmi untuk dijadikan rujukan menganalisa secara spasial. Pengumpulan data merupkan langkah yang sangat penting dalam rangka penelitian. Pada penelitian ini proses pengumpulan data menggunakan metode wawancara disertai permintaan data digital untuk memperkuat hasil pembicaraan lisan tersebut. Penggunaan metode wawancara dalam penelitian ini ditujukan untuk menggali informasi terkait optimalisasi aksesibilitas serta perananannya untuk mempercepat pembangunan di Kabupaten Pangandaran.

\section{HASIL PENELITIAN}

Dalam menentukan bagian mana dari tiga permasalahan yang mendesak untuk diselesaikan maka melakukan analisa Urgency, Seriously, Growth (USG) yang dikembangkan oleh Kepner dan Tragoe (1981), sedangkan penilaian menggunakan Skala Likert 1 - 5 yang masing-masing nilai mewakili prioritas tertentu $(1=$ tidak penting; 2 = 
kurang penting; 3 = penting; 4 = agak penting; 5 = sangat penting). Hasil analisa terhadap permasalahan dijelaskan pada Tabel 4 . berikut ini.

Tabel 4

Tabel Metode USG

\begin{tabular}{|c|l|c|c|c|c|}
\hline NO. & \multicolumn{1}{|c|}{ MASALAH } & URGENCY & SERIOUSLY & GROWTH & TOTAL \\
\hline 1. & $\begin{array}{l}\text { Belum optimalnya koordinasi } \\
\text { kelembagaan di daerah otonomi } \\
\text { baru Kabupaten Pangandaran }\end{array}$ & 5 & 4 & 4 & 14 \\
\hline 2. & $\begin{array}{l}\text { Kurangnya penataan Pedagang } \\
\text { Kaki Lima (PKL) di lokasi- } \\
\text { lokasi pariwisata }\end{array}$ & 5 & 4 & 3 & 12 \\
\hline 3. & $\begin{array}{l}\text { Belum optimalnya } \\
\text { pengendalian pemanfaatan } \\
\text { ruang melalui analisis daya } \\
\text { dukung dan daya tampung } \\
\text { lingkungan }\end{array}$ & 5 & 5 & 5 & 15 \\
\hline
\end{tabular}

Sumber: Hasil Pengolahan

Berdasarkan hasil analisa USG tersebut maka didapatkan nilai total terbesar ada pada masalah nomer 3, sehingga dalam identifikasi masalah dalam penelitian ini dititikberatkan pada belum optimalnya pengendalian pemanfaatan ruang melalui analisis daya dukung dan daya tampung lingkungan.

\subsection{Pelaksanaan Pembangunan Infrastruktur Penataan Jalan di Kabupaten Pangandaran}

Hasil observasi lapangan yang kami lakukan didapatkan bahwa isu utama dalam pembangunan infrastruktur di Kabupaten Pangandaran adalah terkait penataan jalan. Gambaran umum mengenai kondisi jalan dijabarkan sebagai berikut:

A. Kondisi Permukaan Jalan

Berdasarkan informasi dari Dinas PU, kondisi permukaan jalan di Kabupaten Pangandaran adalah sebagai berikut:

- Kondisi Rusak Berat : : 241,55 Km

- Kondisi Rusak Ringan : : 82,76 Km

- Kondisi Sedang $\quad$ : 85,39 Km

- Kondisi Baik : 90,54 Km 
Berdasarkan panjang kondisi permukaan jalan di atas, total panjang jalan yang harus di perbaiki dari total jumlah kondisi rusak berat, rusak ringan dan sedang yaitu panjangnya sebesar 409,7 Km sehingga membutuhkan dana untuk perbaikan berkisar Rp. 819.400.000.000,-

B. Volume Jalan

Selama empat tahun terakhir ini Pemda Kabupaten Pangandaran telah melakukan pembangunan jalan dengan volume sebagai berikut:

- $2013 \quad$ : 42,04 Km

- $2014 \quad: 20,77 \mathrm{Km}$

- $2015 \quad: 60,90 \mathrm{Km}$

- $2016 \quad: 68,35 \mathrm{Km}$

C. Rencana Pembangunan

Pada tahun 2017 Pemda Kabupaten Pangandaran merencanakan pembangunan jalan sepanjang 100,902 Km (Lampiran 1). Menggunakan 2 jenis konstruksi yaitu Rigid sepanjang 66,32 Km dan Hotmix sepanjang 34,51 Km. Rencana pembangunan ini menggunakan anggaran yang berasal APBD Kabupaten sebesar Rp. 77.358.865.000, APBD Provinsi sebesar Rp. 86.170.000.000,- dan DAK sebesar Rp. 46.250.000.000,-

D. Kendala dalam Pembangunan Jalan

Setiap proses pembangunan pasti menghadapi berbagai kendala, termasuk Pemda Kabupaten Pangandaran dalam melakukan pembangunan jalan ini. Adapun kendala yang dihadapi adalah sebagai berikut:

- Keterbatasan material yang berkualitas

- Sulitnya akses jalan menuju lokasi pekerjaan

- Masih belum adanya pemeliharaan jalan secara berkelanjutan

- Faktor Cuaca

\subsection{Kebijakan Penataan Jalan Ditinjau dari Aspek Spasial}

Pemda Kabupaten Pangandaran melalui dokumen RPJMND tahun 2015 - 2021 secara eksplisit menyebutkan bahwa penataan ruang khusunya jalan menjadi prioritas utama dalam menentukan kebijakan umum dan program pembangunan. Hal tersebut juga sejalan dengan misi kedua dari Pemda Kabupaten Pangandaran, yaitu: "Mewujudkan penataan ruang yang harmonis dan pengendalian pemanfaatan ruang yang berwawasan lingkungan". Agar tercapainya misi tersebut diperlukan dukungan program - program yang komprehensif, 
adapun program yang telah dirumuskan oleh Pemda Kabupaten Pangandaran adalah sebagai berikut:

A. Urusan wajib penataan ruang, terdiri dari:

- Program Perencanaan Tata Ruang

- Program Pemanfaatan Ruang; dan

- Program Pengendalian Pemanfaatan Ruang

B. Urusan Wajib Lingkungan Hidup, terdiri dari:

- Program Peningkatan Pengendalian Polusi;

- Program Pengendalian Pencemaran dan Perusakan Lingkungan Hidup;

- Program Pengelolaan dan Rehabilitasi Ekosistem Pesisir dan Laut;

- Program Rehabilitasi dan Pemulihan Cadangan Sumber Daya Alam;

- Program Peningkatan Kualitas dan Akses Informasi Sumber Daya Alam dan Lingkungan Hidup;

- Program Perlindungan dan Konservasi Sumber Daya Alam;

- Program Pengembangan Ekowisata dan Jasa Lingkungan di Kawasan-kawasan Konservasi Laut dan Hutan;

- Program Pengembangan Kinerja Pengelolaan Persampahan; dan

- Program Pengelolaan Ruang Terbuka Hijau.

C. Urusan Wajib Perencanaan Pembangunan, terdiri dari:

- Program Pengembangan Wilayah Strategis dan Cepat Tumbuh;

- Program Kerjasama Pembangunan;

- Program Pengembangan Wilayah Perbatasan;

- Program Perencanaan Pembangunan Daerah;

- Program Perencanaan Pembangunan Ekonomi;

- Program Perencanaan Sosial Budaya;

- Program Perencanaan Wilayah dan Sumber Daya Alam;

- Program Perencanaan Pembangunan Daerah Rawan Bencana;

- Program Perencanaan Pengembangan Kota-kota Menengah dan Besar

Misi Pemda Kabupaten Pangandaran berikutnya terkait penataan jalan yang tertuang dalam misi ketiga adalah: "Menyediakan infrastruktur dan fasilitas yang berkualitas." Jelas yang dimaksud dalam misi tersebut adalah bagaiman pemerintah secara teknis harus 
menyediakan sarana dan prasarana jalan demi kesejahteraan masyarakat sekitar. Adapun program yang terkait untuk mewujudkan misi tersebut adalah:

1. Urusan Wajib Pekerjaan Umum, terdiri dari:

- Program Pembangunan Jalan dan Jembatan;

- Program Peningkatan Jalan dan Jembatan;

- Program Pembangunan Saluran Drainase/Gorong-Gorong;

- Program Pembangunan Turap/Talud/Bronjong;

- Program Rehabilitasi/ Pemeliharaan Jalan dan Jembatan;

- Program Tanggap Darurat Jalan dan Jembatan;

- Program Pembangunan Sistem Informasi/Data Base Jalan dan Jembatan;

- Program Peningkatan Sarana dan Prasarana Kebinamargaan;

- Program Pengembangan dan Pengelolaan Jaringan Irigasi, Rawa dan Jaringan Pengairan Lainnya;

- Program Pengembangan Kinerja Pengelolaan Air Minum dan Air Limbah;

- Program Pengendalian Banjir;

- Program Pengembangan, Pengelolaan dan Konversi Sungai, Danau dan Sumber Daya Air Lainnya;

- Program Penyediaan dan Pengolahan Air Baku;

- Program Pengembangan Wilayah Strategis dan Cepat Tumbuh;

- Program Pembangunan Infrastruktur Perdesaan.

\subsection{Aksesibilitas sebagai Percepatan Pembangunan}

Berdasarkan RPJMD Kabupaten Pangadaran 2015 - 2021 dijelaskan mengenai strategi dan arah kebijakan yang merupakan rumusan perencanaan yang komprehensif tentang bagaimana Pemda mencapai target kinerja yang efektif selama kurun waktu 5 tahun kedepan. Matriks strategi dan arah kebijakan dapat dilihat pada Tabel 5 di bawah ini.

\section{Tabel 5}

Matriks Arah dan Kebijakan Terkait Pengendalan Pemanfaatan Ruang yang Berwawasan Lingkungan 
ISSN : 2337-3067

E-Jurnal Ekonomi dan Bisnis Universitas Udayana 7.5 (2018): 1407-1436

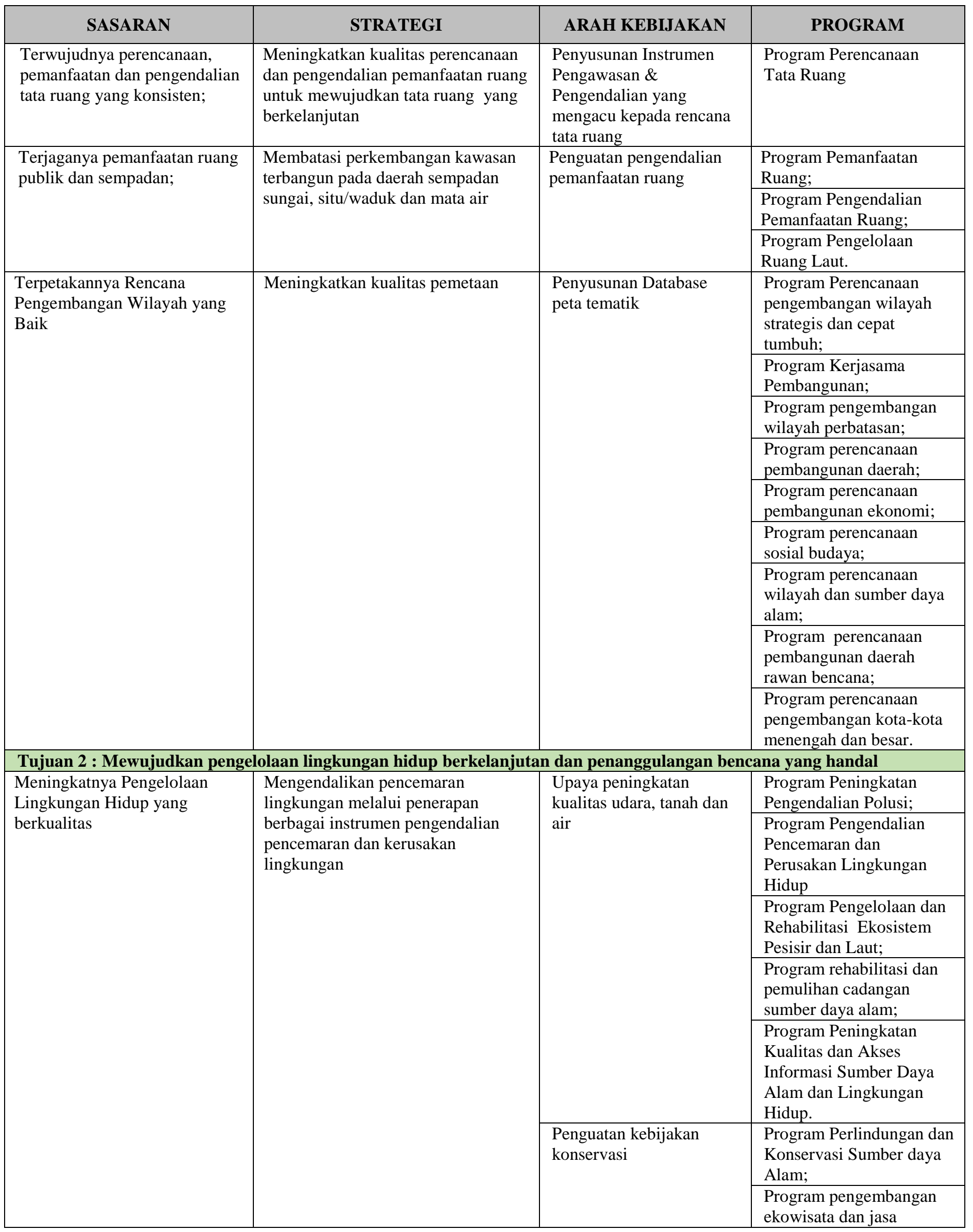




\begin{tabular}{|l|l|l|l|}
\hline \multicolumn{1}{|c|}{ SASARAN } & \multicolumn{1}{|c|}{ STRATEGI } & \multicolumn{1}{|c|}{ ARAH KEBIJAKAN } & \multicolumn{1}{c|}{ PROGRAM } \\
\hline & & $\begin{array}{l}\text { lingkungan di kawasan- } \\
\text { kawasan konservasi laut } \\
\text { dan hutan. }\end{array}$ \\
\hline $\begin{array}{l}\text { Kabupaten Pangandaran Bersih } \\
\text { dan Hijau }\end{array}$ & $\begin{array}{l}\text { Membudayakan kebersihan } \\
\text { lingkungan; }\end{array}$ & $\begin{array}{l}\text { Penguatan Manajemen } \\
\text { Persampahan }\end{array}$ & $\begin{array}{l}\text { Program Pengembangan } \\
\text { Kinerja Pengelolaan } \\
\text { Persampahan. }\end{array}$ \\
\cline { 2 - 4 } & $\begin{array}{l}\text { Peningkatan ruang terbuka hijau } \\
\text { publik dan privat. }\end{array}$ & $\begin{array}{l}\text { Penataan Taman daerah } \\
\text { dan taman terbuka hijau }\end{array}$ & $\begin{array}{l}\text { Program Pengelolaan } \\
\text { Ruang Terbuka Hijau. }\end{array}$ \\
\hline
\end{tabular}

Sumber: Dokumen RPJMD Kabupaten Pangandaran 2016 - 2021

Terkait penyedian infrastruktur yang berkulitas untuk memaksimalkan aksesibilitas demi terwujudnya kesejahteraan masyarakat, Pemda Kabupaten Pangandaran telah menyusun strategi dan arah kebijakan sebagai berikut:

Tabel 6

Matriks strategi dan Arah kebijakan terkait infrastruktur yang berkualitas

\begin{tabular}{|c|c|c|c|}
\hline SASARAN & STRATEGI & ARAH KEBIJAKAN & PROGRAM \\
\hline \multicolumn{4}{|c|}{ Tujuan 1 : Menyediakan Infrastruktur Yang Mendukung Kepariwisataan dan Perekonomian } \\
\hline $\begin{array}{l}\text { Tersedianya jalan yang } \\
\text { menghubungkan antar } \\
\text { objek wisata }\end{array}$ & $\begin{array}{l}\text { Membangun infrastruktur, } \\
\text { prasarana dan sarana } \\
\text { pariwisata }\end{array}$ & $\begin{array}{l}\text { Membangun jalan khusus } \\
\text { pariwisata. }\end{array}$ & $\begin{array}{l}\text { Program pembangunan jalan dan } \\
\text { jembatan. }\end{array}$ \\
\hline \multirow{5}{*}{$\begin{array}{l}\text { Meningkatnya } \\
\text { keandalan sarana dan } \\
\text { prasarana transportasi }\end{array}$} & \multirow{5}{*}{$\begin{array}{l}\text { Pemenuhan sarana } \\
\text { prasarana perhubungan bagi } \\
\text { efektifitas pergerakan } \\
\text { masyarakat Pangandaran, } \\
\text { serta barang dan jasa bagi } \\
\text { perkembangan sentra } \\
\text { produksi dan penghubung } \\
\text { wilayah }\end{array}$} & \multirow{5}{*}{$\begin{array}{l}\text { Peningkatan ketersediaan } \\
\text { sarana dan prasarana } \\
\text { perhubungan }\end{array}$} & $\begin{array}{l}\text { Program Peningkatan Jalan dan } \\
\text { Jembatan; }\end{array}$ \\
\hline & & & $\begin{array}{l}\text { Program rehabilitasi/pemeliharaan } \\
\text { Jalan dan Jembatan; }\end{array}$ \\
\hline & & & $\begin{array}{l}\text { Program tanggap darurat Jalan dan } \\
\text { Jembatan; }\end{array}$ \\
\hline & & & $\begin{array}{l}\text { Program Pembang unan sistem } \\
\text { informasi/ database jalan dan } \\
\text { jembatan; }\end{array}$ \\
\hline & & & $\begin{array}{l}\text { Program peningkatan sarana dan } \\
\text { prasarana kebinamargaan. }\end{array}$ \\
\hline \multirow{3}{*}{$\begin{array}{l}\text { Meningkatnya } \\
\text { keandalan sistem } \\
\text { jaringan infrastruktur } \\
\text { sumber daya air }\end{array}$} & \multirow{3}{*}{$\begin{array}{l}\text { Meningkatkan pemeliharaan } \\
\text { infrastruktur sumber daya } \\
\text { air dan irigasi }\end{array}$} & \multirow{3}{*}{$\begin{array}{l}\text { Pengembangan infrastruktur } \\
\text { sumberdaya air, konservasi } \\
\text { dan pendayagunaan } \\
\text { sumberdaya air, pengendalian } \\
\text { banjir dan daya rusak air serta } \\
\text { pemberdayaan masyarakat } \\
\text { dalam pengelolaan } \\
\text { sumberdaya air; }\end{array}$} & $\begin{array}{l}\text { Program Pembangunan turap/ } \\
\text { talud/bronjong; }\end{array}$ \\
\hline & & & $\begin{array}{l}\text { Program pengembangan dan } \\
\text { pengelolaan jaringan irigasi, rawa } \\
\text { dan jaringan pengairan lainnya; }\end{array}$ \\
\hline & & & Program pengendalian banjir \\
\hline \multirow{3}{*}{$\begin{array}{l}\text { Meningkatnya akses } \\
\text { masyarakat terhadap } \\
\text { sarana prasarana dasar } \\
\text { permukiman }\end{array}$} & \multirow{3}{*}{$\begin{array}{l}\text { Meningkatkan ketersediaan } \\
\text { dan kualitas sarana } \\
\text { prasarana dasar } \\
\text { permukiman. }\end{array}$} & \multirow{3}{*}{$\begin{array}{l}\text { Peningkatan kualitas } \\
\text { perencanaan dan } \\
\text { penyelenggaraan } \\
\text { pembangunan perdesaan } \\
\text { maupun sarana prasarana } \\
\text { dasar permukiman }\end{array}$} & $\begin{array}{l}\text { Program Pembangunan saluran } \\
\text { drainase/gorong-gorong; }\end{array}$ \\
\hline & & & $\begin{array}{l}\text { Program Pengembangan wilayah } \\
\text { strategis dan cepat tumbuh; }\end{array}$ \\
\hline & & & Program infrastruktur Perdesaan. \\
\hline \multirow{2}{*}{$\begin{array}{l}\text { Terwujudnya Destinasi } \\
\text { Pariwisata siap kunjung } \\
\text { yang memiliki } \\
\text { ketahanan dan berdaya }\end{array}$} & $\begin{array}{l}\text { Meningkatkan kualitas } \\
\text { destinasi pariwisata }\end{array}$ & $\begin{array}{l}\text { Peningkatan dan penguatan } \\
\text { destinasi pariwisata berbasis } \\
\text { alam dan budaya; }\end{array}$ & $\begin{array}{l}\text { Program Pengembangan Destinasi } \\
\text { Pariwisata; }\end{array}$ \\
\hline & Meningkatkan kualitas & Peningkatan kualitas desa & Program Pengembangan Desa \\
\hline
\end{tabular}


ISSN : 2337-3067

E-Jurnal Ekonomi dan Bisnis Universitas Udayana 7.5 (2018): 1407-1436

\begin{tabular}{|c|c|c|c|}
\hline SASARAN & STRATEGI & ARAH KEBIJAKAN & PROGRAM \\
\hline \multirow[t]{3}{*}{ saing } & \multirow{3}{*}{$\begin{array}{l}\text { wirausaha, aparatur desa, } \\
\text { khususnya kepariwisataan. }\end{array}$} & & Wisata. \\
\hline & & $\begin{array}{l}\text { Kewirausahaan yang } \\
\text { berkualitas dan berdaya saing }\end{array}$ & $\begin{array}{l}\text { Program Pengembangan } \\
\text { Pemasaran Pariwisata }\end{array}$ \\
\hline & & $\begin{array}{l}\text { Sistem Pemasaran pariwisata } \\
\text { yang integratif, inovatif, tepat } \\
\text { sasaran dan berkelanjutan }\end{array}$ & $\begin{array}{l}\text { Program Pengembangan } \\
\text { Kemitraan. }\end{array}$ \\
\hline \multicolumn{4}{|c|}{ Tujuan 2 : Membangun Pangandaran Kabupaten Cerdas } \\
\hline \multirow{2}{*}{$\begin{array}{l}\text { Tersedianya } \\
\text { Infrastruktur Teknologi } \\
\text { Informasi dan } \\
\text { Komunikasi untuk } \\
\text { Pangandaran Kabupaten } \\
\text { Cerdas }\end{array}$} & \multirow[t]{2}{*}{$\begin{array}{l}\text { Menyusun rencana } \\
\text { pengembangan TIK }\end{array}$} & \multirow{2}{*}{$\begin{array}{l}\text { Mengembangkan infrastruktur } \\
\text { Teknologi Komunikasi dan } \\
\text { Informatika dengan } \\
\text { penguatan Kelembagaannya }\end{array}$} & $\begin{array}{l}\text { Program Pengembangan } \\
\text { Infrastruktur dan Fasilitas TIK; }\end{array}$ \\
\hline & & & $\begin{array}{l}\text { Program Kemitraan untuk } \\
\text { Pembangunan dan Pengembangan } \\
\text { Pemanfaatan TIK. }\end{array}$ \\
\hline \multicolumn{4}{|c|}{ Tujuan 3 : Menyediakan infrastruktur, sarana dan prasarana pemerintahan yang berkualitas } \\
\hline $\begin{array}{l}\text { Tersedianya sarana dan } \\
\text { prasarana pusat } \\
\text { pemerintahan }\end{array}$ & $\begin{array}{l}\text { Membangun sarana } \\
\text { prasarana pusat } \\
\text { pemerintahan }\end{array}$ & $\begin{array}{l}\text { Membangun pusat } \\
\text { pemerintahan modern }\end{array}$ & $\begin{array}{l}\text { Program Peningkatan Sarana dan } \\
\text { Prasarana Aparatur }\end{array}$ \\
\hline \multicolumn{4}{|c|}{ Tujuan 4 : Menyediakan Prasarana dan Sarana Kesehatan yang Representatif } \\
\hline $\begin{array}{l}\text { Terbangunnya Gedung } \\
\text { Rumah Sakit }\end{array}$ & Membangun Rumah Sakit & $\begin{array}{l}\text { Membangun Sarana prasarana } \\
\text { kesehatan }\end{array}$ & $\begin{array}{l}\text { Program Pengadaan, Peningkatan } \\
\text { Sarana dan Prasarana Rumah Sakit }\end{array}$ \\
\hline \multirow[t]{2}{*}{$\begin{array}{l}\text { Terbangunnya Gedung } \\
\text { Puskesmas dan Pustu }\end{array}$} & \multirow[t]{2}{*}{ Membangun Puskesmas } & \multirow{2}{*}{$\begin{array}{l}\text { Peningkatan dan optimalisasi } \\
\text { peranan Pusat Kesehatan } \\
\text { Masyarakat (PUSKESMAS) } \\
\text { dalam memberikan pelayanan } \\
\text { kesehatan kepada masyarakat } \\
\text { di setiap wilayah kecamatan }\end{array}$} & $\begin{array}{l}\text { Program Pengadaan, Peningkatan } \\
\text { dan Perbaikan Sarana dan } \\
\text { Prasarana Puskesmas/ Puskesmas } \\
\text { Pembantu dan Jaringannya; }\end{array}$ \\
\hline & & & $\begin{array}{l}\text { Program Peningkatan Sarana dan } \\
\text { Prasarana Laboratorium Kesehatan }\end{array}$ \\
\hline \multicolumn{4}{|c|}{ Tujuan 5 : Menyediakan Infrastruktur, permukiman dan sanitasi lingkungan yang nyaman } \\
\hline \multirow[t]{2}{*}{$\begin{array}{l}\text { Tersedianya Lingkungan } \\
\text { Permukiman yang Sehat }\end{array}$} & \multirow{2}{*}{$\begin{array}{l}\text { Meningkatkan kondisi } \\
\text { sarana dan prasarana dasar } \\
\text { permukiman }\end{array}$} & \multirow{2}{*}{$\begin{array}{l}\text { Penataan rumah tidak layak } \\
\text { huni melalui penyediaan } \\
\text { hunian yang layak dan } \\
\text { terjangkau bagi seluruh } \\
\text { lapisan masyarakat. }\end{array}$} & $\begin{array}{l}\text { Program pengembangan } \\
\text { perumahan; }\end{array}$ \\
\hline & & & $\begin{array}{l}\text { Program Pengembangan } \\
\text { Lingkungan Sehat Perumahan. }\end{array}$ \\
\hline $\begin{array}{l}\text { Tersedianya Taman } \\
\text { Makam Pahlawan dan } \\
\text { Pemakaman Umum } \\
\end{array}$ & $\begin{array}{l}\text { Menyediakan taman } \\
\text { pahlawan dan pemakaman } \\
\text { umum }\end{array}$ & $\begin{array}{l}\text { Menata dan menertiban taman } \\
\text { makam pahlawan dan } \\
\text { pemakaman umum }\end{array}$ & $\begin{array}{l}\text { Program Pengelolaan Areal } \\
\text { Pemakaman. }\end{array}$ \\
\hline \multirow{5}{*}{$\begin{array}{l}\text { Meningkatnya } \\
\text { penanggulangan } \\
\text { bencana dan } \\
\text { perlindungan } \\
\text { masyarakat }\end{array}$} & \multirow[t]{5}{*}{$\begin{array}{l}\text { Peningkatan layanan } \\
\text { penanggulangan bencana }\end{array}$} & \multirow[t]{5}{*}{$\begin{array}{l}\text { Pencegahan dini dan } \\
\text { penanggulangan bencana }\end{array}$} & $\begin{array}{l}\text { Program pencegahan dini dan } \\
\text { penanggulangan korban bencana } \\
\text { alam; }\end{array}$ \\
\hline & & & $\begin{array}{l}\text { Program pening katan } \\
\text { kesiapsiagaan dan pencegahan } \\
\text { bencana alam; }\end{array}$ \\
\hline & & & $\begin{array}{l}\text { Program peningkatan dan } \\
\text { penguatan kapasitas kelembagaan; }\end{array}$ \\
\hline & & & $\begin{array}{l}\text { Program Penanganan Daerah- } \\
\text { daerah Pasca Bencana; }\end{array}$ \\
\hline & & & $\begin{array}{l}\text { Program Peningkatan Kesiagaan } \\
\text { dan Pencegahan Bahaya } \\
\text { Kebakaran. }\end{array}$ \\
\hline $\begin{array}{l}\text { Terwujudnya } \\
\text { infrastruktur sanitasi dan } \\
\text { air bersih yang } \\
\text { berkualitas dan merata }\end{array}$ & $\begin{array}{l}\text { Meningkatkan akses } \\
\text { layanan untuk sistem } \\
\text { pengolahan limbah terpusat } \\
\text { dan komunal domestik non } \\
\text { domestik }\end{array}$ & $\begin{array}{l}\text { Meningkatakan akses layanan } \\
\text { air limbah melalui sistem } \\
\text { terpusat, komunal maupun } \\
\text { individu untuk limbah } \\
\text { domestik dan non domestik }\end{array}$ & $\begin{array}{l}\text { Program pengembangan, } \\
\text { pengelolaan dan konversi sungai, } \\
\text { danau dan sumber daya air lainnya }\end{array}$ \\
\hline
\end{tabular}




\begin{tabular}{|c|c|c|c|}
\hline SASARAN & STRATEGI & ARAH KEBIJAKAN & PROGRAM \\
\hline & \multirow{2}{*}{$\begin{array}{l}\text { Mengembangkan dan } \\
\text { memelihara Sumber air } \\
\text { Baku untuk penyediaan air } \\
\text { bersih dalam rangka } \\
\text { meningkatkan cakupan dan } \\
\text { kontinuitas pelayanan air } \\
\text { bersih }\end{array}$} & $\begin{array}{l}\text { Mendorong peningkatan } \\
\text { layanan dan akses masyarakat } \\
\text { terhadap air minum; }\end{array}$ & $\begin{array}{l}\text { Program Pengem bangan kinerja } \\
\text { pengelolaan air minum dan air } \\
\text { limbah; }\end{array}$ \\
\hline & & $\begin{array}{l}\text { Mendorong pelestarian } \\
\text { sumber-sumber air baku } \\
\text { untuk air minum }\end{array}$ & $\begin{array}{l}\text { Program penyediaan dan } \\
\text { pengolahan air baku. }\end{array}$ \\
\hline \multicolumn{4}{|c|}{ Tujuan 6 : Mewujudkan Sistem Transportasi yang aman, nyaman, efisien, memadai, handal dan aman } \\
\hline \multirow[t]{6}{*}{$\begin{array}{l}\text { Terwujudnya sistem } \\
\text { transportasi yang handal }\end{array}$} & \multirow{5}{*}{$\begin{array}{l}\text { Menyediakan prasarana dan } \\
\text { fasilitas perhubungan yang } \\
\text { memadai }\end{array}$} & $\begin{array}{l}\text { Peningkatan sarana dan } \\
\text { prasarana dasar perhubungan }\end{array}$ & $\begin{array}{l}\text { Program pembangunan prasarana } \\
\text { dan fasilitas perhubungan. }\end{array}$ \\
\hline & & $\begin{array}{l}\text { Pembangunan sarana dan } \\
\text { prasarana angkutan laut dan } \\
\text { sungai }\end{array}$ & $\begin{array}{l}\text { Program rehabilitasi dan } \\
\text { pemeliharaan prasarana dan fasilitas } \\
\text { LLAJ }\end{array}$ \\
\hline & & $\begin{array}{l}\text { Menyediakan fasilitas } \\
\text { terminal yang layak }\end{array}$ & $\begin{array}{l}\text { Program peningkatan pelayanan } \\
\text { angkutan }\end{array}$ \\
\hline & & $\begin{array}{l}\text { Rehabilitasi dan pemeliharaan } \\
\text { prasarana dan fasilitas } \\
\text { perhubungan }\end{array}$ & $\begin{array}{l}\text { Program pembangunan sarana dan } \\
\text { prasarana perhubungan }\end{array}$ \\
\hline & & $\begin{array}{l}\text { Meningkatkan kelaikan } \\
\text { pengoperasian kendaraan } \\
\text { bermotor }\end{array}$ & $\begin{array}{l}\text { Program Peningkatan kelaikan } \\
\text { pengoperasian kendaraan bermotor }\end{array}$ \\
\hline & $\begin{array}{l}\text { Mengendalikan aspek-aspek } \\
\text { kemacetan }\end{array}$ & $\begin{array}{l}\text { Menyediakan fasilitas } \\
\text { kelengkapan jalan (Rambu, } \\
\text { Marka, Traffic light, paku } \\
\text { jalan, marka parkir dll) }\end{array}$ & $\begin{array}{l}\text { Program Peningkatan dan } \\
\text { Pengamanan Lalu lintas }\end{array}$ \\
\hline
\end{tabular}

Sumber: Dokumen RPJMD Kabupaten Pangandaran 2016-2021

\subsection{Analisis SWOT}

Selanjutnya, melakukan pembahasan penelitian dengan menggunakan analisa SWOT. Analisa menggunakan metode SWOT memudahkan penulis dalam memetakan lingkungan internal dan eksternal di Kabupaten Pangandaran. Secara lebih detil perihal analisis lingkungan internal dan eksternal akan dijelaskan lebih lanjut.

\subsubsection{Analisis Lingkungan Internal}

Berdasarkan analisis yang dilakukan pada lingkungan internal, akan dapat diidentifikasi faktor-faktor kekuatan dan kelemahan yang dimiliki oleh Kabupaten Pangandaran. Karena bersifat internal, semua faktor kekuatan dan faktor kelemahan ini berada dalam jangkauan kapasitas pemerintah daerah untuk mempengaruhinya.

\section{A. Analisis Kekuatan (Strenght)}

1) Pemekaran wilayah Kabupaten Pangandaran memberikan keleluasaan dan peluang yang lebih besar bagi Pemerintah Daerah dalam memberikan pelayanan publik lebih cepat;

2) Kabupaten Pangandaran memiliki Daerah Tujuan Wisata (DTW) yang bervariasi mulai dari wisata alam, wisata budaya dan juga wisata minat khusus/buatan; 
3) Memiliki garis pantai cukup panjang dan memiliki ciri khas bahwa pantainya bisa sekaligus melihat terbit dan tenggelamnya matahari dari tempat yang sama;

4) DTW di Kabupaten Pangandaran relatif tersebar merata di seluruh kecamatan yang ada;

5) Dukungan masyarakat terhadap pengembangan sektor pariwisata sangat tinggi karena sesuai dengna kondisi lingkungan.

B. Analisis Kelemahan (Weaknesses)

1) Sistem kelembagaan dan kebijakan pembangunan belum terkoordinasi secara sempurna sehingga kegiatan pemerintahan belum berjalan secara optimal;

2) Hingga saat ini RTRW Kabupaten Pangandaran belum disahkan menjadi Perda, sehingga berbagai regulasi yang terkait dengan proses penataan ruang, seperti aturan tata guna lahan dan zonasi belum dapat dilakukan secara baik;

3) Kondisi infrastruktur dasar (jalan) yang masih menyebabkan aksesibilitas ke sebagian wilayah dirasakan sulit serta menghambat konektivitas dan pengembangan pembangunan;

4) Tingkar daya saing masyarakat Kabupaten Pangandaran masih rendah sehingga perlu ditingkatkan agar mampu mendorong pembangunan yang efisien dan efektif serta berkelanjutan;

5) Program kemitraan dengan masyarakat lokal masih kurang dilaksanakan dalam industri pariwisata.

\subsubsection{Analisis Lingkungan Eksternal}

Seperti juga pada analisis lingkungan internal, maka analisis lingkungan eksternal juga terdiri atas dua faktor yaitu, faktor peluang dan faktor ancaman. Karena bersifat eksternal, sebagian besar dari faktor peluang dan ancaman berada diluar jangkauan pemerintah daerah untuk mempengaruhinya, atau paling tidak kemampuan pemerintah daerah untuk mempengaruhi faktor peluang dan ancaman adalah lebih terbatas kalau dihadapi secara terfokus dan bertahap.

\section{A. Peluang (Opportunity)}

1) Kabupaten Pangandaran ditetapkan sebagai Kawasan Andalan Nasional Priangan Timur - Pangandaran berdasarkan RTRW Provinsi Jawa Barat 2009 - 2029 (Perda Nomor 22 Tahun 2010;

2) Penetapan Kabupaten Pangandaran sebagai salah satu Kawasan Strategis Pariwisata Nasional menurut PP Nomor 50 tahun 2011 tentang RIPPARNAS 2010 - 2025 dan 
juga Perda Jawa Barat Nomor 12 tahun 2014 dimana Kabupaten Pangandaran ditetapkan sebagai salah satu Pusat Pertumbuhan Provinsi;

3) Potensi kunjungan dari wisata mancanegara akan meningkat karena ditetapkannya Zona Masyarakat Ekonomi Asean (MEA);

4) Berkembangnya industri kreatif berbasis pada aktivitas pariwisata di seluruh wilayah Indonesia memberi dampak dalam mendorong aktivitas pariwisata dan ekonomi kreatif di Kabupaten Pangandaran.

5) Rencana pembangunan infrastruktur dalam RPJMN 2015 -2019 (Perpres Nomor 21 Tahun 2015) seperti perluasan Bandara Nusawiru milik Pemprov Jawa Barat, dan Pembangunan Pelabuhan Bojongsalawe oleh Kementerian Perhubungan akan memberikan efek yang cukup luas bagi terciptanya peningkatan ekonomi di Kabupaten Pangandaran.

B. Ancaman (Threat)

1) Pengaruh globalisasi membuat produk-produk import mudah masuk, sementara daya saing masyarakat yang terbilang rendah;

2) Akses teknologi informasi, komunikasi dan modernisasi yang begitu kuat dapat menyebabkan berubahnya nilai-nilai sosial budaya masyarakat di Kabupaten Pangandaran;

3) Kondisi geografis Kabupaten Pangandaran secara alamiah berada pada daerah rawan bencana, baik bencana tsunami, pergerakan tanah dan juga banjir;

4) Hasil survey dalam laporan Ripparda menunjukkan ada kecenderungan DTW yang aktivitas pariwisatanya sudah berkembang akan berkorelasi dengan penurunan kualitas lingkungan di DTW tersebut, yang tidak menjamin keberlangsungan pembangunan wisata yang berkelanjutan;

5) Ketidakstabilan perekonomian dunia menyebabkan penurunan daya beli masyarakat internasional, sehingga mempengaruhi kedatangan wisatawan mancanegara maupun domestik di Kabupaten Pangandaran.

Tabel 7

Matriks Analisis SWOT

\begin{tabular}{|c|c|}
\hline Strengths & Weaknesses \\
\hline $\begin{array}{l}\text { 1. Pemekaran wilayah Kabupaten Pangandaran } \\
\text { memberikan keleluasaan dan peluang yang lebih } \\
\text { besar bagi Pemerintah Daerah dalam memberikan } \\
\text { pelayanan publik lebih cepat; } \\
\text { 2. Kabupaten Pangandaran memiliki Daerah Tujuan }\end{array}$ & $\begin{array}{l}\text { 1. Sistem kelembagaan dan kebijakan pembangunan } \\
\text { belum terkoordinasi secara sempurna sehingga } \\
\text { kegiatan pemerintahan belum berjalan secara } \\
\text { optimal; } \\
\text { 2. Hingga saat ini RTRW Kabupaten Pangandaran }\end{array}$ \\
\hline
\end{tabular}


Wisata (DTW) yang bervariasi mulai dari wisata alam, wisata budaya dan juga wisata minat khusus/buatan;

3. Memiliki garis pantai cukup panjang dan memiliki ciri khas bahwa pantainya bisa sekaligus melihat terbit dan tenggelamnya matahari dari tempat yang sama;

4. DTW di Kabupaten Pangandaran relatif tersebar merata di seluruh kecamatan yang ada;

5. Dukungan masyarakat terhadap pengembangan sektor pariwisata sangat tinggi karena sesuai dengna kondisi lingkungan. belum disahkan menjadi Perda, sehingga berbagai regulasi yang terkait dengan proses penataan ruang, seperti aturan tata guna lahan dan zonasi belum dapat dilakukan secara baik;

3. Kondisi infrastruktur dasar (jalan) yang masih menyebabkan aksesibilitas ke sebagian wilayah dirasakan sulit serta menghambat konektivitas dan pengembangan pembangunan;

4. Tingkar daya saing masyarakat Kabupaten Pangandaran masih rendah sehingga perlu ditingkatkan agar mampu mendorong pembangunan yang efisien dan efektif serta berkelanjutan;

5. Program kemitraan dengan masyarakat lokal masih kurang dilaksanakan dalam industri pariwisata.

\section{Opportunities}

1. Kabupaten Pangandaran ditetapkan sebagai Kawasan Andalan Nasional Priangan Timur Pangandaran berdasarkan RTRW Provinsi Jawa Barat 2009 - 2029 (Perda Nomor 22 Tahun 2010;

2. Penetapan Kabupaten Pangandaran sebagai salah satu Kawasan Strategis Pariwisata Nasional menurut PP Nomor 50 tahun 2011 tentang RIPPARNAS 2010 - 2025 dan juga Perda Jawa Barat Nomor 12 tahun 2014 dimana Kabupaten Pangandaran ditetapkan sebagai salah satu Pusat Pertumbuhan Provinsi;

3. Potensi kunjungan dari wisata mancanegara akan meningkat karena ditetapkannya Zona Masyarakat Ekonomi Asean (MEA);

4. Berkembangnya industri kreatif berbasis pada aktivitas pariwisata di seluruh wilayah Indonesia memberi dampak dalam mendorong aktivitas pariwisata dan ekonomi kreatif di Kabupaten Pangandaran.

5. Rencana pembangunan infrastruktur dalam RPJMN 2015 -2019 (Perpres Nomor 21 Tahun 2015) seperti perluasan Bandara Nusawiru milik Pemprov Jawa Barat, dan Pembangunan Pelabuhan Bojongsalawe oleh Kementerian Perhubungan akan memberikan efek yang cukup luas bagi terciptanya peningkatan ekonomi di Kabupaten Pangandaran.
1. Pengaruh globalisasi membuat produk-produk import mudah masuk, sementara daya saing masyarakat yang terbilang rendah;

2. Akses teknologi informasi, komunikasi dan modernisasi yang begitu kuat dapat menyebabkan berubahnya nilai-nilai sosial budaya masyarakat di Kabupaten Pangandaran;

3. Kondisi geografis Kabupaten Pangandaran secara alamiah berada pada daerah rawan bencana, baik bencana tsunami, pergerakan tanah dan juga banjir;

4. Hasil survey dalam laporan Ripparda menunjukkan ada kecenderungan DTW yang aktivitas pariwisatanya sudah berkembang akan berkorelasi dengan penurunan kualitas lingkungan di DTW tersebut, yang tidak menjamin keberlangsungan pembangunan wisata yang berkelanjutan;

5. Ketidakstabilan perekonomian dunia menyebabkan penurunan daya beli masyarakat internasional, sehingga mempengaruhi kedatangan wisatawan mancanegara maupun domestik di Kabupaten Pangandaran.

Tabel 8

\begin{tabular}{|c|c|c|}
\hline \multicolumn{3}{|c|}{ Penyusunan Alternatif Strategis } \\
\hline \multirow{3}{*}{ INTERNAL } & KEKUATAN & KELEMAHAN \\
\hline & $\begin{array}{l}\text { Kabupaten Pangandaran memiliki } \\
\text { Daerah Tujuan Wisata (DTW) } \\
\text { tersebar merata di seluruh } \\
\text { kecamatan yang ada }\end{array}$ & $\begin{array}{l}\text { Tingkat daya saing masyarakat } \\
\text { Kabupaten Pangandaran masih } \\
\text { rendah }\end{array}$ \\
\hline & $\begin{array}{l}\text { Dukungan masyarakat terhadap } \\
\text { pengembangan sektor pariwisata } \\
\text { sangat tinggi }\end{array}$ & $\begin{array}{l}\text { Program kemitraan dengan } \\
\text { masyarakat lokal masih kurang } \\
\text { dilaksanakan dalam industri } \\
\text { pariwisata }\end{array}$ \\
\hline PELUANG & STRATEGI S-O & $\begin{array}{l}\text { STRATEGI W-O } \\
\end{array}$ \\
\hline
\end{tabular}




\begin{tabular}{|c|c|c|}
\hline $\begin{array}{l}\text { Potensi kunjungan dari wisata } \\
\text { mancanegara akan meningkat } \\
\text { karena ditetapkannya Zona } \\
\text { Masyarakat Ekonomi Asean } \\
\text { (MEA) }\end{array}$ & \multirow{3}{*}{$\begin{array}{l}\text { Diperlukan peningkatan } \\
\text { pembangunan infrastruktur berupa } \\
\text { jalan, bandara dan pelabuhan untuk } \\
\text { mempermudah aksesibilitas arus } \\
\text { masuk dan keluar dari dan ke } \\
\text { Kabupaten Pangandaran, sehingga } \\
\text { mempercepat pertumbuhan } \\
\text { ekonomi masyarakat Kabupaten } \\
\text { Pangandaran. }\end{array}$} & \multirow{3}{*}{$\begin{array}{l}\text { Mendorong penguatan program } \\
\text { kemitraan dengan masyarakat } \\
\text { lokal untuk peningkatan daya } \\
\text { saing masyarakat Kabupaten } \\
\text { Pangandaran dari sektor ekonomi } \\
\text { kreatif berdasarkan referensi dari } \\
\text { wilayah lain di Indonesia. }\end{array}$} \\
\hline $\begin{array}{l}\text { Rencana pembangunan } \\
\text { infrastruktur dalam RPJMN } 2015 \text { - } \\
2019 \text { (perluasan bandara } \\
\text { Nusawiru, pembangunan } \\
\text { Pelabuhan Bojongsalawe) }\end{array}$ & & \\
\hline $\begin{array}{l}\text { Berkembangnya industri kreatif } \\
\text { berbasis pada aktivitas pariwisata } \\
\text { di seluruh wilayah Indonesia }\end{array}$ & & \\
\hline ANCAMAN & $\begin{array}{l}\text { STRATEGI S-T } \\
\end{array}$ & $\begin{array}{l}\text { STRATEGI W-T } \\
\end{array}$ \\
\hline $\begin{array}{l}\text { Kondisi geografis Kabupaten } \\
\text { Pangandaran secara alamiah } \\
\text { berada pada daerah rawan } \\
\text { bencana, baik bencana tsunami, } \\
\text { pergerakan tanah dan juga banjir }\end{array}$ & \multirow{2}{*}{$\begin{array}{l}\text { Diperlukan koordinasi dengan } \\
\text { Pemerintah pusat terkait } \\
\text { penanggulangan/antisipasi } \\
\text { terjadinya bencana tanpa } \\
\text { meminimalisir potensi wisata yang } \\
\text { ada, misalnya penyediaan } \\
\text { teknologi Tsunami Early Warning } \\
\text { System (TEWS). }\end{array}$} & \multirow{2}{*}{$\begin{array}{l}\text { Diberikannya pelatihan kepada } \\
\text { unit usaha kecil dan menengah } \\
\text { yang bergerak di bidang pariwisata } \\
\text { lokal agar produk yang dihasilkan } \\
\text { mampu bersaing dengan produk } \\
\text { impor. Pelatihan diberikan mulai } \\
\text { dari hulu hingga hilir. }\end{array}$} \\
\hline $\begin{array}{l}\text { Pengaruh globalisasi membuat } \\
\text { produk-produk import mudah } \\
\text { masuk, sementara daya saing } \\
\text { masyarakat yang terbilang rendah }\end{array}$ & & \\
\hline
\end{tabular}

Sumber: Diolah oleh penulis

Berdasarkan matriks penyusunan alternatif strategis pada tabel diatas, maka dapat disimpulkan bahwa strategi yang dapat dilakukan adalah:

a. Diperlukan peningkatan pembangunan infrastruktur berupa jalan, bandara dan pelabuhan untuk mempermudah aksesibilitas arus masuk dan keluar dari dan ke Kabupaten Pangandaran, sehingga mempercepat pertumbuhan ekonomi masyarakat Kabupaten Pangandaran.

b. Mendorong penguatan program kemitraan dengan masyarakat lokal untuk peningkatan daya saing masyarakat Kabupaten Pangandaran dari sektor ekonomi kreatif berdasarkan referensi dari wilayah lain di Indonesia.

c. Diperlukan koordinasi dengan Pemerintah pusat terkait penanggulangan/antisipasi terjadinya bencana tanpa meminimalisir potensi wisata yang ada, misalnya penyediaan teknologi Tsunami Early Warning System (TEWS).

d. Diberikannya pelatihan kepada unit usaha kecil dan menengah yang bergerak di bidang pariwisata lokal agar produk yang dihasilkan mampu bersaing dengan produk impor. Pelatihan diberikan mulai dari hulu hingga hilir. 


\subsection{Alternatif Pembukaan Jalan Penghubung Baru}

Posisi strategis Kabupaten Pangandaran yang berbatasan dengan Kabupaten lain di Jawa Barat (Kabupaten Ciamis, Kota Banjar dan Kabupaten Tasikmalaya) dan Provinsi Jawa Tengah menjadi salah satu pusat pertumbuhan, maka diperlukan investasi dalam bidang infrastruktur jalan penghubung baru (bukan jalan provinsi) untuk mendukung dan mendorong agar pariwisata di Kabupaten Pangandaran semakin berkembang. Jalan penghubung baru yang kami rekomendasikan untuk dibuka aksesnya adalah jembatan putra pinggan yang terletak di Desa Putrapinggan, daerah Kalipucang. Saat ini kondisi jembatan putra pinggan terputus dikarenakan amblas sejak 9 oktober 2016, apabila jalan tersebut diperbaiki dan diperbesar aksesnya, maka beberapa manfaat dan keuntungan yang akan didapat diantaranya:

1. Jalan tersebut akan menghubungkan jalan-jalan lokal yang ada

2. Terbukanya konektivitas tempat-tempat wisata, pusat pemerintahan, perdagangan, pendidikan, dan lainnya yang ada di daerah Pangandaran

3. Mempercepat gerak ruang aktivitas masyarakat urban dan lokal, misalnya rencana pembangunan Rumah Sakit Umum Daerah (RSUD)

4. Dokumen Rencana Tata Ruang Wilayah (RTRW) dapat diwujudkan dengan lebih baik

5. Percepatan pencapaian target RPJMD Kabupaten Pangandaran

6. Meningkatkan perekonomian masyarakat lokal sekitar daerah Desa Putrapinggan

\subsection{Tinjauan secara Geologi}

Selanjutnya pada sub-bab ini kan dibahas secara lebih teknis terkait tema penelitian ini. Jembatan putra pinggan yang terletak di Desa Putra Pinggan, daerah Kalipucang terletak di dataran tinggi dengan ketinggian $927 \mathrm{mdpl}$ dan kemiringan rata-rata $28^{\circ}$, sehingga dimungkinkan untuk dilakukan pelebaran badan jalan. Lebih jelas mengenai kondisi jalan tersebut dapat dilihat pada Gambar 4 dibawah ini. 


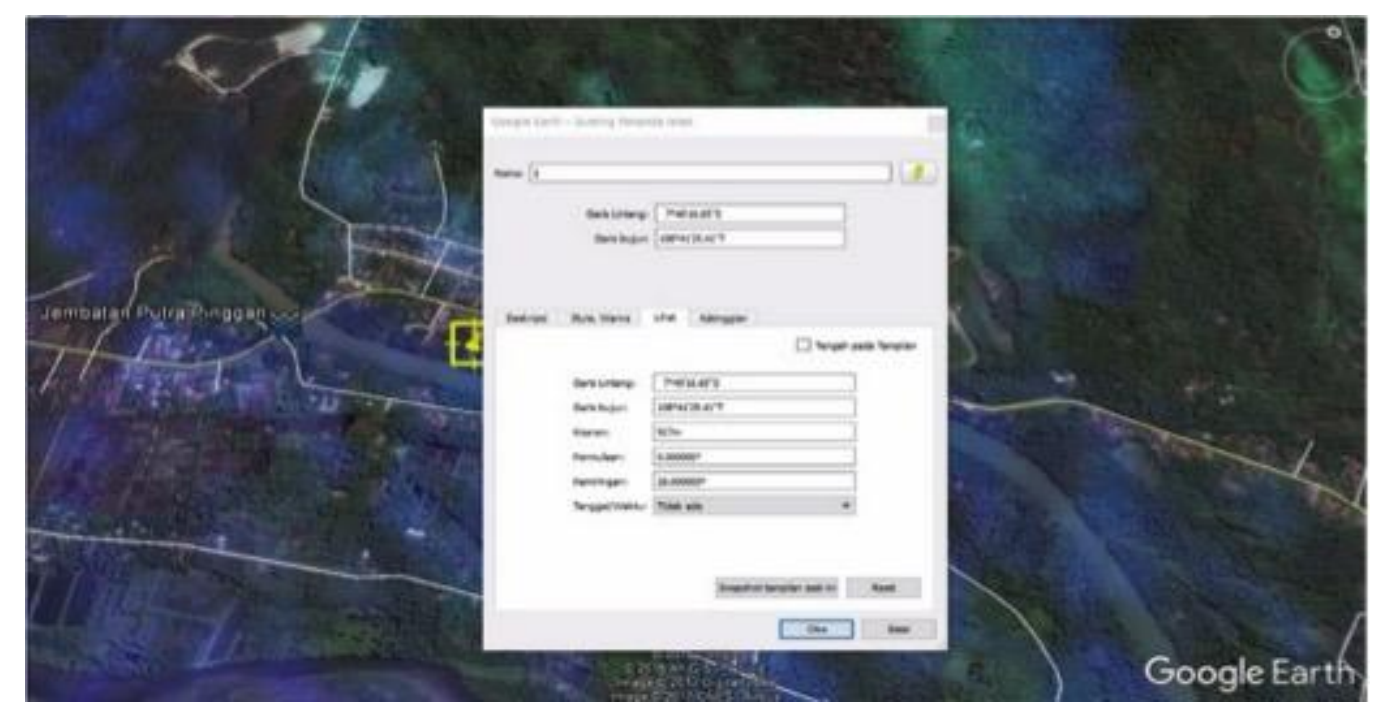

Gambar 4. Tampilan Jembatan Putra Pinggan Dilihat melalui Citra Google Earth

Sumber: https://www.google.com/earth

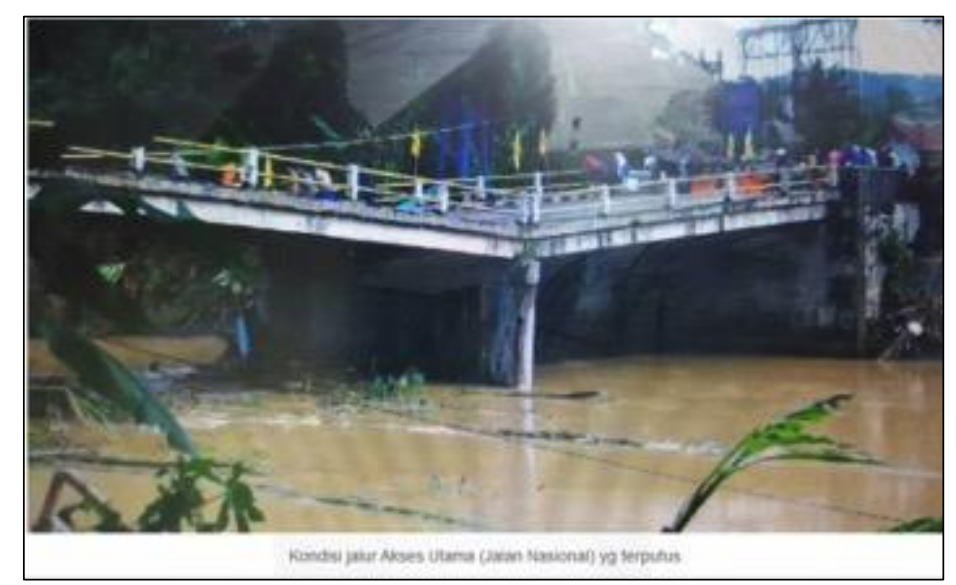

Gambar 5 Photo Jembatan Putra Pinggan (Kondisi Eksisting)

Sumber: http://news.okezone.com/read/2016/10/10/525/1510652/jembatan-jalan-nasional-menuju-

pangandaran-ditutup-total

Daerah tersebut termasuk aman untuk dilakukan pembangunan dikarenakan sifat erosi permukaan sedang cukup tinggi, setempat-setempat merupakan daerah berbakat longsor terutama pada tufa lapuk (pelapukan).

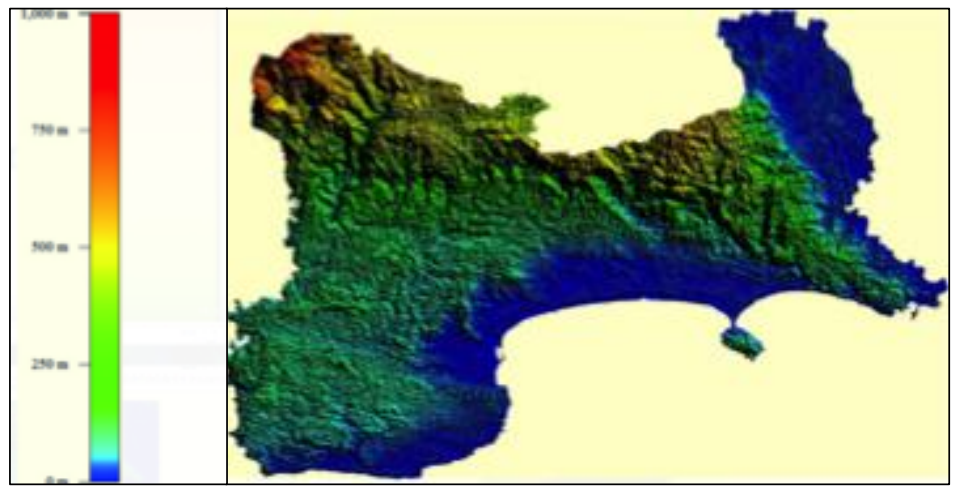

Gambar 6 Profil ketinggian wilayah Pangandaran 
Sumber: Badan Geologi Provinsi Jawa Barat

Aksesibilitas wilayah yang berdekatan dengan jalur reaktivasi kereta api dari kota Banjar menuju Bandara Nusawiru, sehingga menjadi alternatif akses menuju Kabupaten Pangandaran. Muka air tanah dangkal cukup dalam lebih 5m, umumnya dapat diperoleh dilembah-lembah, untuk muka air tanah antara $8>10 \mathrm{~m}$, akan mendapatkan air agak jernih dengan $\mathrm{pH}$ antara 6,5 - 7,5 sehingga area tersebut layak untuk dikembangkan.

\section{KESIMPULAN}

Berdasarkan hasil penelitian, analisis data, dan pembahasan hasil penelitian tentang optimalisasi aksesibilitas sebagai percepatan pembangunan, mala dapat diambil kesimpulan sebagai berikut:

1. Pelaksanaan pembangunan infrastruktur terkait penataan jalan di Kabupaten Pangandaran saat ini merupakan prioritas utama kegiatan pembangunan. Karena kondisi jalan yang ada saat ini dapat dikatakan kurang layak dan merupakan warisan dari Kabupaten Ciamis. Penataan jalan di Kabupaten Pangandaran direncanakan pada tahun 2017 sepanjang 100,902 Km dengan peningkatan yang signifikan sebesar 67,73\% dari tahun sebelumnya. Kondisi jalan yang layak dan memadai akan meningkatkan kondisi perekonomian masyarakat serta peningkatan PAD Kabupaten Pangandaran pada sektor pariwisata khususnya

2. Kebijakan penataan jalan merupakan hal yang mendesak, karena jika ditinjau dari aspek spasial Kabupaten Pangandaran berada pada wilayah yang rawan bencana. Disisi lain kondisi topologi dan geografi Kabupaten Pangandaran yang penuh tantangan menjadi alasan tersendiri mengapa penataan jalan menjadi prioritas.

3. Aksesibilitas dapat meningkatan percepatan pembangunan di Kabupaten Pangandaran, hal ini karena letak Kabupaten Pangandaran yang strategis dan menjadi jalur daerah tujuan wisata. Bahkan secara eksplisit disebutkan pada Perda No. 12 Tahun 2014 Provinsi Jawa Barat dimana Kabupaten Pangandaran ditetapkan sebagai salah satu pusat perumbuhan Provinsi.

Hasil dari penelitian ini memunculkan sebuah sumbang saran bagi Kabupaten Pangandaran khususnya dan informasi untuk dunia akademis, adapun saran yang penulis ingin sampaikan adalah sebagai berikut:

1. Pemda Kabupaten Pangandaran diharapkan memiliki pemahaman berkelanjutan dalam kegiatan penataan jalan demi terciptannya kesejahteraan masyarakat; 
2. Koordinasi dengan pemerintah Provinsi dan Pusat secara reguler dan berksenimabungan terkait wilayah Kabupaten Pangandaran yang dijadikan proyek Provinsi/Nasional;

3. Meningkatkan peran partisipasi masyarakat secara intensif agar kegiatan pembangunan khusunya penataan jalan dapat terealisasi sesuai harapan masyarakat.

\section{REFERENSI}

Arsyad, lincolin, (1999). Pengantar Perencanaan Pembangunan Ekonomi Daerah. Yogyakarta : BPFE

Evans, et al. (2009). Differentiating Classroom Climate Concepts: Academic, Management, And Emotional Environments. New Zealand Journal of Social Sciences Online

Kepner, C.H. \& Benjamin, T.B., (1981). Manajer Yang Rasional Edisi Terjemahan. Jakarta: Erlangga.

Muta'ali, Lutfi. (1999). Penerapan Konsep Pusat Pertumbuhan Dalam Kebijaksanaa Pengembangan Wilayah. Yogyakarta: Fakultas Geografi Universitas Gajah Mada

Oppenheim,. (1980). Applied Models in Urban and Regional Analysis. First Edition, Prentice Hall, Englewood Cliffs, 1980, ISBN No. 0-13-041467-0

Rangkuti, F. 2001. Analisis SWOT Teknik Membedah Kasus Bisnis. PT. Gramedia Pustaka Utama, Jakarta.

Rencana Pembangunan Jangka Menengah Daerah Kabupaten Pangandaran Tahun 2016-2021

Taringan, Robinson. (2004). Perencanaan Pembangunan Wilayah. Jakarta: PT bumi aksara

Undang-undang No. 21 Tahun 2012 Tentang Pembentukan Kabupaten Pangandaran. Provinsi Jawa Barat.

Undang-undang No. 23 Tahun 2014 tentang otonomi Daerah 